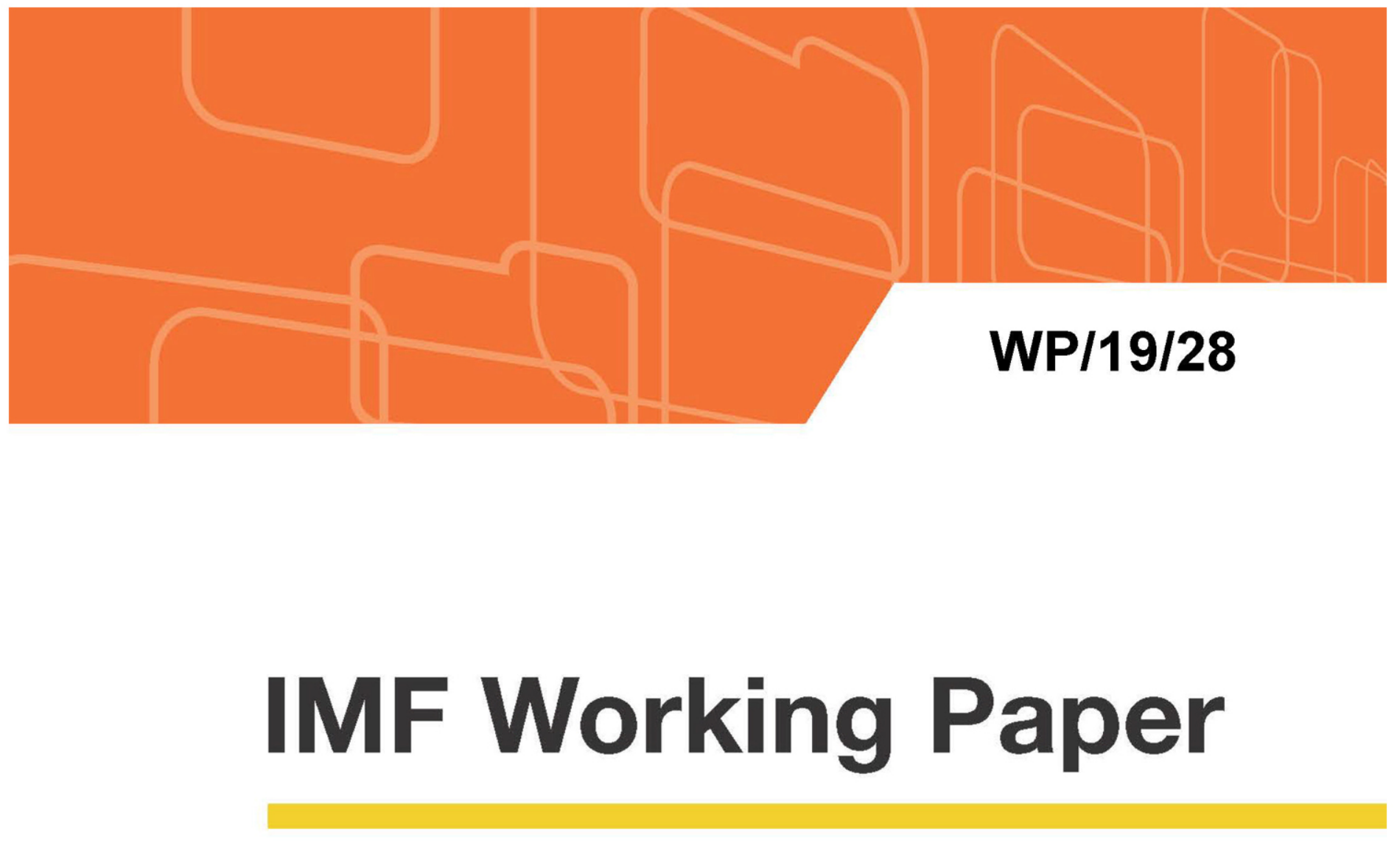

\title{
Mobilization Effects of Multilateral Development Banks
}

by Chiara Broccolini, Giulia Lotti, Alessandro Maffioli, Andrea F. Presbitero and Rodolfo Stucchi

IMF Working Papers describe research in progress by the author(s) and are published to elicit comments and to encourage debate. The views expressed in IMF Working Papers are those of the author(s) and do not necessarily represent the views of the IMF, its Executive Board, or IMF management.

$$
\text { I N T E R N A T I O N A L M O N E T A R Y F U N D }
$$




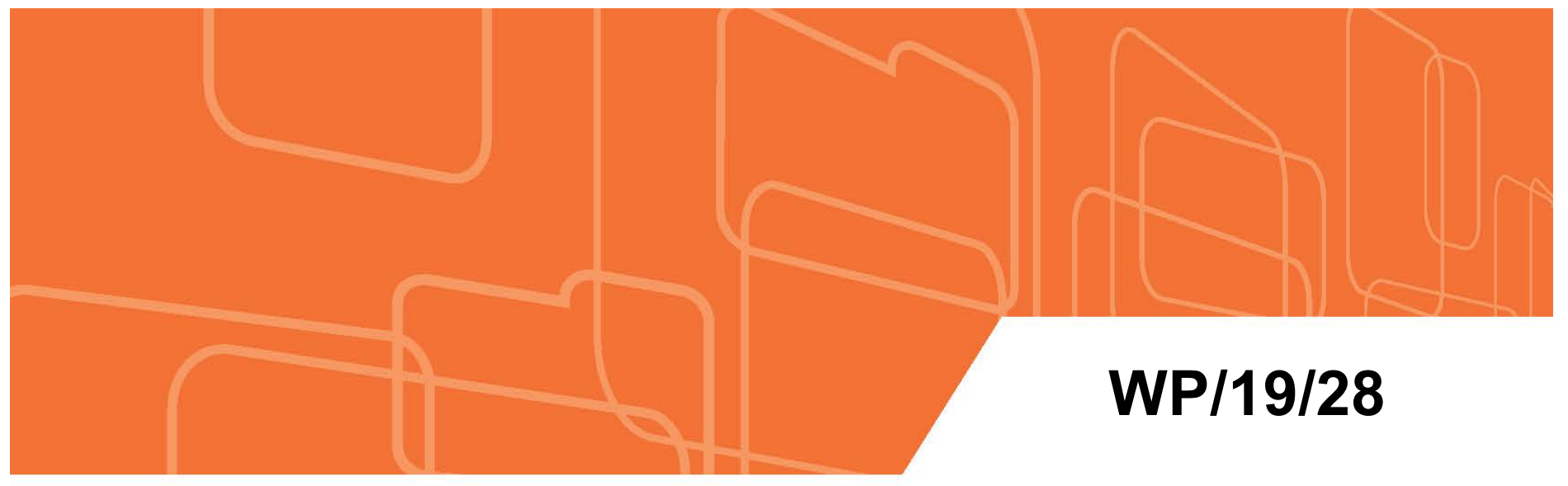

\section{IMF Working Paper}

\section{Mobilization Effects of Multilateral Development Banks}

by Chiara Broccolini, Giulia Lotti, Alessandro Maffioli, Andrea F. Presbitero and Rodolfo Stucchi

IMF Working Papers describe research in progress by the author(s) and are published to elicit comments and to encourage debate. The views expressed in IMF Working Papers are those of the author(s) and do not necessarily represent the views of the IMF, its Executive Board, or IMF management.

$$
\text { I N T E R N A T I O N A L M O N E T A R Y F U N D }
$$




\title{
IMF Working Paper
}

\author{
Research Department
}

\section{Mobilization Effects of Multilateral Development Banks ${ }^{1}$}

\section{Prepared by Chiara Broccolini, Giulia Lotti, Alessandro Maffioli, Andrea F. Presbitero and Rodolfo Stucchi}

Authorized for distribution by Maria Soledad Martinez Peria

February 2019

IMF Working Papers describe research in progress by the author(s) and are published to elicit comments and to encourage debate. The views expressed in IMF Working Papers are those of the author(s) and do not necessarily represent the views of the IMF, its Executive Board, or IMF management.

\begin{abstract}
We use loan-level data on syndicated lending to a large sample of developing countries between 1993 and 2017 to estimate the mobilization effects of multilateral development banks (MDBs), controlling for a large set of fixed effects. We find evidence of positive and significant direct and indirect mobilization effects of multilateral lending on the number of deals and on the total size of bank inflows. The number of lending banks and the average maturity of syndicated loans also increase after MDB lending. These effects are present not only on impact, but they last up to three years and are not offset by a decline in bond financing. There is no evidence of anticipation effects and the results are not driven by confounding factors, such as the presence of large global banks, Chinese lending and aid flows. Finally, the economic effects are sizable, suggesting that MBDs can play a vital role to mobilize private sector financing to achieve the goals of the 2030 Development Agenda.
\end{abstract}

JEL Classification Numbers: F21, F34, G15, H81

Keywords: Multilateral Development Banks, Private Capital Flows, Mobilization Effects, Catalytic Finance, Syndicated loans

Authors’ E-Mail Addresses: broccolini.chiara@gmail.com, glotti@iadb.org, alessandrom@iadb.org, apresbitero@imf.org, rstucchi@iadb.org

\footnotetext{
${ }^{1}$ We thank Tito Cordella, Daniel Gurara, participants at the "International Conference on Blended Development Finance and the New Industrial Policy" (Geneva 2018) and at seminars at the IDB and the IMF for helpful comments on earlier drafts. This paper is part of a project on Macroeconomic Research in Low-Income Countries (project id: 60925) supported by the U.K.'s Department for International Development. The views expressed in this paper are those of the author and do not necessarily represent those of the IDB, IMF, IMF policy, or of the DFID.
} 


\section{Contents}

1 Introduction $\quad \underline{4}$

2 Data

3 Empirical Strategy $\quad \underline{10}$

4 Results $\quad \underline{12}$

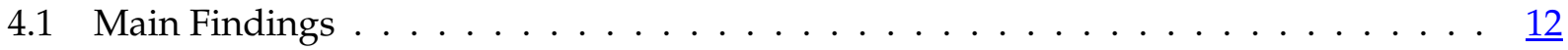

4.2 Robustness ......................... 13

5 Extensions $\quad \underline{17}$

5.1 Direct and Indirect Effects $\ldots \ldots \ldots \ldots \ldots \ldots \ldots$

5.2 Is There a Crowding Out of Corporate Bonds? . . . . . . . . . . . . 18

5.3 Sector Heterogeneity $\ldots \ldots \ldots \ldots \ldots \ldots$

5.4 Country Heterogeneity $\ldots \ldots \ldots \ldots \ldots \ldots \ldots$

6 Conclusions $\quad \underline{23}$

A Figures $\quad \underline{30}$

B Tables $\quad \underline{32}$

C Online Appendix-Not for publication $\underline{44}$ 


\section{Introduction}

In 2015, 193 countries adopted the 2030 Sustainable Development Agenda, which set ambitious targets for poverty reduction and inclusive development. The United Nations estimates that achieving the Sustainable Development Goals (SDGs) will require investment up to USD 3.9 trillion per year. At current investment levels, the estimated annual investment gap in developing countries is at about USD 2.5 trillion (UNCTAD, 2014). At the same time, total official development assistance (ODA) amounted to USD 143 billion in 2016, one order of magnitude smaller than the needs. This leaves a key role for the private sector.

An important question - for both policy and research-is how can the international community mobilize those additional resources for investment. In this respect, Multilateral Development Banks (MDBs), as international institutions that provide financial assistance (e.g. loans, grants, etc.) to developing countries to promote their economic and social development, ${ }^{1}$ can play a fundamental role, directly providing financial assistance in developing countries, but also mobilizing additional private sector resources. The first role, direct financial support to member countries, is part of the mandate of MDBs, which are expected to step in when private financing is scarce (Humphrey and Michaelowa, 2013), possibly mitigating the pro-cyclicality of private capital inflows (Galindo and Panizza, 2018). But direct financing is constrained by the fact that MDBs' loan capacity is small compared to countries' needs: demand for financing exceeds supply well beyond what MDBs can finance directly (United Nations, 2015). For this reason, MDBs have recently reaffirmed their pledge to catalyze more investment from private investors (World Bank, 2018).

There are multiple examples from around the world of projects with MDBs' participation that had important catalytic effects in different settings. A prominent example is the Panama Canal expansion. The project to expand the canal and allow larger ships to transit to avoid market losses followed a referendum in 2006 and was financed by the Inter-American Development Bank Group (IDBG), other three Multilaterals, and the Japan Bank for International Cooperation. It is the largest infrastructure investment in the country since the Canal opened-amounting to 30\% of GDP - and in the 5 years after its announcement it is estimated to have raised almost USD 9.9 billion in private investment, 1.8 times the project cost (Lanzalot et al., 2018). In 2017, IDBG also financed the operation of the 70 megawatt Uruguayan wind farm, Campo Palomas. The operation attracted interest towards the nascent renewable energy market in Uruguay, and international in-

\footnotetext{
${ }^{1}$ See Table A1 for a list of MDBs in the analysis.
} 
stitutional investors oversubscribed. Eventually, five investors participated, of which four were new to Uruguay, and US\$135.8 million were mobilized. ${ }^{2}$ In Tanzania, the Tanzania Electric Supply Company (TANESCO), the European Investment Bank (EIB) and several other MDBs financed the Backbone Interconnector Project to enable better power distribution and the reliability of power supply. The project became active in 2017 and catalyzed private investment estimated at 0.5-0.8 times the total costs (USD 228 million, World Bank, 2018). In India, the International Finance Corporation (IFC) launched a rupee bond program in offshore markets, later named the Masala Bond Program, which allowed Indian entities to access international investors that they would have not reached otherwise. The currency risk was borne by foreign investors, that could in turn benefit from the strong fundamentals of the Indian emerging economy. The total private catalyzation from private institutional investors residing offshore was estimated to amount 6.2 USD billions (Shi, 2017; World Bank, 2018).

There are different channels through which MDBs can leverage additional resources from the private sector. For example, MDBs can indirectly mobilize additional private finance as their entrance in a given country/sector could signal future investment opportunities. Also, thanks to their long-term perspective, MDBs could promote macroeconomic stability, growth and an investmentfriendly environment, ${ }^{3}$ all factors that can attract private creditors (Eichengreen and Mody, 2000; Kidwelly, 2017). In a similar vein, the presence of MDBs itself can signal to the private market the donors' trust in the country's institutional capacity and its commitment to reform, raising creditworthiness and consequently private capital inflows (Morris and Shin, 2006; Basílio, 2014). MDBs can also directly mobilize private resources thanks to the reduction of political and credit risks. In the first case, MDBs can use their leverage to influence governmental decisions and deter adverse events that would negatively affect the project outcome (Hainz and Kleimeier, 2012). Credit risk could be reduced through multilateral guarantees and the extension of the MDBs' preferred creditor status, which implies that their loans are excluded from debt reschedulings (Arezki et al., 2017; Pereira dos Santos and Kearney, 2018; Gurara et al., 2018). In addition, to overcome or mitigate information asymmetries, private creditors can be willing to co-invest in the loan syndication with an MDB to take advantage of its technical expertise, monitoring capacity and better knowledge of

\footnotetext{
${ }^{2}$ See https:/ / www.iadb.org and Inter-American Development Bank Group (2018).

${ }^{3}$ Through advisory and knowledge work MDBs can help governments identify and implement reforms to improve the investment environment and remove barriers to investments. Moreover, by encouraging countries experiencing balance of payments crises to pursue an IMF-supported program, or offering emergency financing to address macroeconomic vulnerabilities only after the IMF has assessed that an appropriate macroeconomic framework is in place, they can help restore macroeconomic stability (Group of Twenty, 2018).
} 
the country/sector (Chelsky et al., 2013; Ratha, 2001; Gurría et al., 2001).

However, MDB lending could be a substitute rather than a complement to private finance, leading to crowding out rather than crowding in of private capital inflows (Basílio, 2014; Bird and Rowlands, 2007). Lack of additionality could simply be the result of the fact that MDB lending may displace private investors which would have invested anyway. Moreover, private inflows might also be discouraged if multilateral lending creates incentives for moral hazard, with borrowing governments financing low-returns projects, delaying reforms or using lending to repay old debt (Ratha, 2001; Swaroop and Devarajan, 1999). Crowding out could also originate from the fact that MDBs impose higher environmental, social, and governance standards, monitor development outcomes-which is costly-and may interfere with corporate strategy. Finally, countries may need to borrow from MDBs when they are excluded from private markets and MDB lending could signal severe economic distress, discouraging private investment.

In light of these arguments and the anecdotal evidence discussed above, in this paper we focus on MDBs' participation in syndicated lending to formally test whether MDBs crowd in private sector resources to finance investment in developing countries. The existing evidence is mostly focused on IMF lending, but its catalytic effect-the capacity to attract private investment after the provision of official assistance (Giannini and Cottarelli, 2002; Morris and Shin, 2006) — cannot be easily generalized to MDBs, given its nature of crisis lending. ${ }^{4}$ A smaller strand of literature has explicitly focused on MDBs and, using aggregate macroeconomic data, finds mixed results. Rodrik (1995) tests whether net transfers from multilateral sources to a country are a predictor of subsequent net private capital inflows, controlling for past private flows. Using country data averaged over four periods of six years (from 1970 to 1993), he does not find a significant association between past multilateral lending and current private flows. With a similar framework, Ratha (2001) finds instead that multilateral lending has a positive impact on private flows in a large sample of developing countries. Consistent with this result, Dasgupta and Ratha (2000) also find that private capital flows respond positively to past World Bank lending commitments.

As the studies on the catalytic effect of international financial institutions makes it clear, esti-

\footnotetext{
${ }^{4}$ Theoretically, Corsetti et al. (2006) and Morris and Shin (2006) show that IMF catalytic financing can reduce the incidence of panic-driven liquidity crises. Empirically, Eichengreen and Mody (2001), Mody and Saravia (2006) and Eichengreen et al. (2006) use transaction data of individual bonds issuances and find the IMF programs can have a catalytic effect, conditional on country fundamentals being only moderately bad. In a review of economics and politics of the IMF, Bird (2007) warns against any generalization from the empirical evidence, as results do not appear robust and consistent across methodologies, samples and economic conditions. More recently, Erce and Riera-Crichton (2015) use aggregate data on gross capital flows to show that while the IMF does not appear able to catalyze foreign capital, there is substantial evidence that it does affect the behavior of resident investors, who are less likely to place their savings abroad and more likely to repatriate their foreign assets.
} 
mating the effect of the presence of MDBs on private capital flows requires to deal with selection bias and the endogeneity of MDB lending (Carter et al., 2018). In particular, as the choice by the MDBs to invest in a country/sector is not exogenous, the identification of causal effects is impaired by the fact that macro data do not allow to understand if private lending would have happened also without the MDBs' involvement. Our approach, based on more granular loan level data, has the advantage of absorbing all time-varying country- and sector-specific factors which could drive MDB lending via a large set of fixed effects. In particular, by exploiting country-sector level data, we are able to control not only for country- and year- fixed effects, but also for country-sector, country-year, and sector-year fixed effects; hence, we greatly diminish the possibility of omitted variable bias and increase accuracy in the estimation of the mobilization effects.

Our results—based on regressions at country-sector-year level-indicate that the number of loans, the amount of syndicated lending, the average number of lending banks per loan, and the average loan maturity increase in the years following the presence of a syndicated loan with MDBs' participation in a given country-sector-year. The average effects are economically sizable-and even larger when focusing on infrastructure loans-and last for at least up to three years, suggesting that MDBs can play a vital role to mobilize resources to help achieving the SDGs and meet the ambitious aims of the 2030 Development Agenda. To further mitigate lingering concerns of reverse causality and omitted variable bias, we show that there are no anticipation effects and that controlling for a set of confounding factors-the presence of the largest global banks, Chinese lending and aid flows in the country-sector pair-does not affect the significance and the size of the estimated MDBs' mobilization effects.

The granularity of the data allows us to estimate total mobilization effects too, which include direct and indirect effects. Looking at contemporaneous effects, we find evidence of direct mobilization effects, suggesting that MDBs can attract private flows both directly, through risk mitigation, and indirectly, thanks to signaling and demonstration effects. Nonetheless, since our baseline analysis looks exclusively at syndicated loans, one may argue that the mobilization effect could be partially or completely offset by a reduction in other debt flows. We deal with this concern looking at corporate bond issuances and we do not find any evidence that bond financing declines after an MDB starts lending in a given country-sector pair. ${ }^{5}$

Finally, we perform a number of extensions, showing that the mobilization effects are stronger

\footnotetext{
${ }^{5}$ We focus on the potential substitution between corporate bonds and syndicated loans, as they constitute two similar sources of financing from a firm's perspective (Altunbaş et al., 2010), while the role of the equity market in developing countries is still relatively limited (World Bank, 2015; Cortina et al., 2018).
} 
for more financially developed countries and for those with better credit ratings. Consistent with this evidence, we find that mobilization effects are weaker and often non statistically significant if we restrict the analysis to low-income countries, while periods of low economic growth seem not to be a binding constraints, in line with the development mandate of MDBs.

Our contribution to the literature is twofold. First, we depart from the literature on catalytic finance that has mainly discussed the catalytic role of the IMF by focusing specifically on the role of MDBs, which have been greatly overlooked so far and can instead be an important player in light of the 2030 Development Agenda. Second, while the literature has mainly focused on case studies or country-aggregate data, our analysis is based on loan-level data from the international market of syndicated loans and covers a large sample of more than 100 countries from 1993 to 2017. In this way, we can better isolate the effect of MDBs' participation on subsequent bank flows (as well as loan terms), exploit heterogeneity across sectors to focus on infrastructure financing, and try to disentangle the mechanisms through which MDBs can mobilize private sector resources. To the best of our knowledge, we provide the first assessment, fully based on loan-level data, of the mobilization effects of MDBs, a key channel to catalyze the private sector and finance investment and growth in developing countries.

The remainder of this paper is organized as follows. Sections 2 and 3 describe the data and the empirical strategy, respectively. Results and a set of robustness checks are discussed in Section 4. Section 5 introduces a number of extensions and Section 6 concludes.

\section{Data}

Our main source of data is the Dealogic Loan Analytics database, which contains micro data at the level of tranches of all syndicated loans of 127 developing countries from 1993 to 2017. Syndicated loans are provided by a syndicate, e.g. a group of lenders, that share risks by pooling together capital. They have been used for decades and are now becoming a dominant way to tap banks, finance companies and institutional investors (Miller, 2006). Their relevance has been expanding dramatically and they have become a key source of funding for corporations in both developing countries and advanced economies (Bruche et al., 2017; Cortina et al., 2018).

In line with existing studies (e.g., Nini, 2004; Carey and Nini, 2007; Cortina et al., 2018), we exclude loans to public authorities, as they are likely driven by different factors compared to loans to non-sovereign entities (private sector and public sector firms). As a result, we are left with 21,373 
syndicated loans to 117 countries: 51 percent of those loan deals are destined to Asia, 27 percent to the Americas, 15 percent to Europe, 7 percent to Africa, and 0.3 percent to Oceania. The countries with the majority of syndicated loans across the period are India, Brazil, Russia, Indonesia, Turkey and Mexico, as shown by the largest bubbles in Figure 1. The countries with the greatest share of loans supported by MDBs are Afghanistan, Tajikistan, Vanuatu, Belize, Kyrgyzstan and Moldova, as shown by the darker bubbles in the same chart. Over time the number of syndicated loans has increased, despite some drops during major financial crises, as shown in Figure 2.

The information in the data is comprehensive, including signing date, nationality of the borrower, total value of the deal in USD, maturity of each tranche, the general industry group of the deal and the name of the lending banks. We also have information on deal type, specifically, whether the syndicated loan is an investment grade, leveraged or highly leveraged loan. ${ }^{6}$ Thanks to the information on the lender, we are able to distinguish the syndicated loans in which there is the participation of at least one MDB. The MDBs participate in the syndicated loans markets at commercial terms through their private-sector windows to mobilize financing for domestic and foreign creditors. MDBs operate under a joint financial and development mandate, which differentiate them from commercial banks. In our sample, the largest players are the European Investment Bank (EIB), the European Bank for Reconstruction and Development (EBRD) and the International Finance Corporation (IFC)—see Table A1. Deals that involve MDBs are 11.1 percent of the sample and they are, on average, significantly larger, with longer maturities, and with fewer non-MDB banks involved (Table 1).

We group the information on the general industry of the syndicated loans into 9 sectors: agriculture, construction and real estate, finance, government, infrastructure, manufacturing, mining and metals, oil and gas, services. The majority of loans belong to the finance, infrastructure, and manufacturing sectors, which are also the sectors with the majority of loans with MDBs' participation.

To prevent large countries to drive the results, we use nominal GDP in USD from the World Economic Outlook (WEO) as a scaling factor for the total value of the syndicated loan. Scaling by GDP also gives us a better understanding of the relative magnitude of the loan size with respect to the country's economy. For data cleaning purposes we winsorize the top and bottom 1 percent of total amount scaled by GDP of syndicated loans.

\footnotetext{
${ }^{6}$ This characterization refers to the borrowers credit rating, with investment grade loans being issued to higher-rated borrowers, while leveraged loans are for below-investment-grade borrowers. Most are investment grade loans (62.94 percent), the rest are leveraged. There is a small percentage (4.62 percent) of syndicated loans that are highly leveraged.
} 
With this information we build a balanced panel at the country-sector level. In total, we have 26,325 observations corresponding to 1,053 country-sectors (117 countries and 9 sectors) that we observe for 25 years.

Our main outcome variables of interest are: 1) the number of syndicated loans in the countrysector, excluding deals the with MDB participation; 2) the total size of the syndicated loans (as a share of GDP), excluding both the amount lent by the MDBs and by their partners in the syndicate; 3) the number of banks per loan excluding those partnering only in deals with MDBs' participation; and 4) the average loan maturity. ${ }^{7}$ To shed light on the mechanisms that drive mobilization effects, we later also explore direct mobilization effects by looking at: 5) the number of banks that participate in syndicated lending per loan; and 6) the total size of the syndicated loans (as a share of GDP), excluding the amount lent by MDBs themselves, but including that lent by banks co-investing in a syndicated loan with MDBs' participation.

Table 2 reports the summary statistics for the country-sector panel data. On average there are 0.7 syndicated loans in each country-sector-year (Panel A). The average total value of loans in a country-sector-year is 0.11 percent of GDP, which is only slightly higher that the average total value of loans excluding the ones supported by MDBs. The average number of banks (excluding MDBs) involved in syndicated loans is 1.56 , similar to the average number of banks without counting the ones partnering in a syndicated loan with MDBs. The average maturity of loans, without counting loans with MDB participation, is 8.7 months.

Finally, to test whether MDB syndicated loans crowd out corporate bonds, we use the information on bond issuances provided by Dealogic for 67 developing countries over the period 19932017. Panel B reports the summary statistics for corporate bond issuances, which refer to a smaller sample than that of syndicated loans. On average, bond issuances in the country-sector pair are more numerous than syndicated loans, but the size in percent of GDP is smaller.

\section{Empirical Strategy}

A key advantage of using loan-level data is that we can set-up our dataset at the country-sectoryear level and look at new loans in a given country-sector pair after an MDB has entered that country-sector co-financing a syndicate loan, controlling for time-varying unobservable factors

\footnotetext{
${ }^{7}$ The data provides the maturity of each tranche of syndicated loans. We calculate the weighted average of the maturities of syndicated loans by weighting the maturity of each tranche by its relative size within the loan. Once we collapse the dataset at the country-sector-year level, we calculate the average of weighted maturities of syndicated loans in the country-sector-year.
} 
both at the country and sector level. Thus, we evaluate whether the presence of an MDB attracts private capital by estimating the following equation:

$$
y_{c s, t}=\sum_{k=0}^{2} \beta_{k} M D B_{c s, t-k}+\delta_{c, t}+\zeta_{s, t}+\alpha_{c s}+\varepsilon_{c s, t}
$$

where $y_{c s, t}$ is the outcome variable in country-sector pair $c s$ at time $t$. As anticipated in the previous section, in the paper we explore effects on different outcome variables defined at the countrysector-year level: 1) the number of syndicated loans; 2) the total size of syndicated loans, scaled by GDP; 3) the average number of banks involved per syndicated loans; and 4) the average loan maturity of syndicated loans, in years. When measuring the outcome variables, in the baseline analysis we focus on indirect mobilization and we always exclude the loans with MDBs' participation. In additional analyses, we exploit the richness of the dataset to disentangle direct and indirect mobilization effects and compute the number of banks and loan size including also the partners of the MDBs and the amount they lend in the loan with MDBs' participation; see Section 5.1.

Our key explanatory variable $\left(M D B_{c s, t}\right)$ is a dummy equal to one if there is at least one deal supported by MDBs in the country-sector pair $c s$ at time $t$. The coefficient $\beta_{0}$ of $M D B_{c s, t}$ measures the contemporaneous MDBs' (indirect) mobilization effect. However, to allow for the possibility that mobilization effects show up with a lag, we include up to two lags of $M D B_{c s, t-k}$ and then calculate the cumulative effect between year $t-2$ and $t\left(\beta_{0}+\beta_{1}+\beta_{2}\right)$. To rule out that there is an increase in the outcome variables before MDBs' participation, in the robustness section we also test for the presence of any anticipation effect including up to two leads of the MDB dummy variable.

We saturate the model with a large set of fixed effects. Time-varying country $\left(\delta_{c, t}\right)$ and sector $\left(\zeta_{s, t}\right)$ fixed effects absorb any time-varying global shock, as well as country- and sector-specific unobserved factors which could drive bank lending, such as changes in credit demand and local economic conditions. The country $\times$ sector fixed effects $\left(\alpha_{c s}\right)$ further reduces the threat of omitted variable bias by controlling for all time-invariant differences in observables and unobservables between country-sector pairs. Thus, our strategy relies on the assumption that there are no unobservable factors that vary over time within each country-sector pair and are also correlated with changes in the MDB dummy variable. That is, we have to assume that all the unobservables of country-sectors do not change in time, which seems a plausible assumption. ${ }^{8}$

We follow Abadie et al. (2017) and cluster the standard errors $\left(\varepsilon_{c s, t}\right)$ at the country level, under

\footnotetext{
${ }^{8}$ We then relax this assumption controlling for a set of variables which vary at the country-sector-year level, including the presence of the top 10 banks in the syndicate market, aid flows and Chinese lending; see Section 4.2.
} 
the conservative assumption that MDBs' support is assigned at the country level and that mobilization effects vary by country. As a robustness check we also cluster standard errors at the country-sector level, to account for the possibility that in reality MDBs' support is assigned at the country-sector level; see Section 4.2.

\section{Results}

\subsection{Main Findings}

Table 3 shows the results of estimating equation 1 for the different outcome variables. In each regression we control for country $\times$ sector, country $\times$ year and sector $\times$ year fixed effects. Column 1 shows that having at least one syndicated loan supported by at least one MDB is associated with an increase of 0.82 syndicated loans in the following year. The second lag of $M D B_{c s, t}$ indicates that the increase in the number of syndicated loans at the country-sector level is not limited to the year $t+1$, but persists in the second year after the MDB participation. The contemporaneous effect is similar in magnitude, but not statistically significant. The cumulative effect from $t$ to $t+2$ is equal to 2.45 and is statistically significant. Given that there are on average 0.76 syndicated loans in a country-sector-year, the catalytic effect on the number of loans is economically large.

Column 2 reports the estimated effects of MDBs' participation on the total amount (in percent of GDP) lent to private borrowers in the country-sector pair. Loan size excludes the amount granted by the MDBs themselves and the amount lent by their partners in the syndicated loans—so that we are estimating the indirect mobilization effect of MDB lending. We find that country-sector pairs that have at least one MDB participating in syndicated loans experience a volume of syndicated loans in the same year which is $0.07 \%$ of GDP higher than country-sector pairs without MDBs' presence. There is no additional effect in the following year, but there is evidence of a smaller lagged effect after two years. The cumulative effect between year $t-2$ and year $t$ is equal to $0.16 \%$ of GDP, which corresponds to about 150 percent of the average size of syndicated loans to private creditors in a country-sector-year (which is equal to $0.11 \%$ of GDP, see Table 2). If we scale this effect by the size of the average syndicated loan (also equal to $0.11 \%$ of GDP, see Table 1 ), we still observe that the cumulative effect is economically large. Overall, these results are of the same order of magnitude as those reported by the anecdotal evidence on mobilization effects discussed in Section 1.

Column 3 assesses whether multilateral lending attracts other banks as lenders to the country- 
sectors. We find that when MDBs participate, there are on average 0.55 extra banks participating in syndicated lending to the country-sector pair in the same year. The effect is persistent over time, with similar magnitudes each year. The cumulative effect over three years, equal to almost 2 additional lending banks per loan, is economically large, given that, on average, there are 1.52 banks per syndicated loans per year at the country-sector level.

Finally, in column 4 we look at loan maturity. The results indicate that when MDBs participate in syndicated loans, the average weighted loan maturity in a country-sector pair increases by 0.36 years in the same year. Similarly to the mobilization effects found for size, we also observe a significant lengthening of the average maturity at time $t+2$. The cumulative effect is precisely estimated and close to 0.8 years of additional length in loan maturity.

\subsection{Robustness}

In this section we test the robustness of our baseline results to: i) two major threats to identification (the possible presence of anticipation effects and confounding factors), ii) the role of extreme values, iii) the choice of the model specification, and iv) an alternative clustering of the standard errors.

Anticipation effects. Even though our empirical setting controls for a large set of unobserved factors that could drive syndicated lending, reverse causality remains a concern, as MDBs could follow private capital inflows and enter country-sector pairs which have been receiving more and larger syndicated loans. Since in the baseline we only include time-invariant country $\times$ sector fixed effects, we are not able to completely rule out that reverse causality could drive our results. To mitigate this concern, we test for anticipation effects by adding up to 2 leads of the variable $M D B_{c s, t}$ to equation 1 , so that we estimate the following model:

$$
y_{c s, t}=\sum_{k=-2}^{+2} \beta_{k} M D B_{c s, t-k}+\delta_{c, t}+\zeta_{s, t}+\alpha_{c s}+\varepsilon_{c s, t}
$$

All our results are robust to the inclusion of leads of the MDB participation dummy and there are no anticipation effects, as reported in Table 4. The coefficients of $M D B_{c s, t+1}$ and $M D B_{c s, t+2}$ are not significantly different from zero for the number of loans, for the size of loans, for the average number of banks per loan and for the average maturity, indicating that MDBs do not enter in markets where the number, value of loans, number of banks per loan and maturity are already 
increasing.

Confounding factors. In all our estimates we are able to control for unobserved time-varying country and sector factors that can drive private lending. Although we also include country $\times$ sector fixed effects, our baseline set of fixed effects cannot control for the possibility that other players enter a country-sector pair and attract further resources from private creditors. To address this concern, we run a set of additional regressions.

First, we want to rule out the possibility that the effect we capture is not driven by MDBs, but by the fact that some large global bank, very active in the syndicate loan market, starts lending to a given country-sector pair, and the presence of a large global player is what really drives subsequent private sector financing, as well as the presence of MDBs. To this end, we re-estimate our baseline model controlling for the presence of the top 10 largest private banks according to S\&P. ${ }^{9}$ We do so by including in equation 1 a dummy variable equal to 1 if at least one of the top 10 banks was present in the country-sector in the previous 2 years. ${ }^{10}$ Results are shown in Table 5. Even though, as one would expect, the presence of top banks has a predictive power for all our outcomes except the number of loans, the estimate of the mobilization effects of MDBs are not affected. In particular, the cumulative effects remain statistically significant and qualitatively similar to those of the baseline (Table 3).

Second, we further control for other sources of financing that might affect the participation of private creditors at the country-sector level, zooming in on the role of Chinese lending and, more generally, on aid flows. In this way, we address lingering concerns that we are not capturing growth opportunities at the country-sector level which may jointly attract MDBs and private lenders.

Chinese lending to developing countries has grown considerably since the 2000s, reaching close to USD 40 billion per year between 2011 and 2014, more than US overseas flows (Dreher et al., 2017). Since Chinese lending is primarily driven by economic interests and is correlated with higher economic growth (Dreher et al., 2017, 2018), the presence of Chinese-funded projects could also be associated with subsequent private sector lending (as well as MDBs participation). We can test this hypothesis thanks to the detailed project-level data collected by AidData on Chi-

\footnotetext{
${ }^{9}$ We consider the top 10 banks by assets as classified by S\&P. Banks were ranked by total assets as of December 31 , 2017. The top 10 include: JPMorgan Chase \& Co., Bank of America Corp., Wells Fargo \& Co., Citigroup Inc., Goldman Sachs Group Inc., Morgan Stanley, Credit Suisse Group AG, U.S. Bancorp, Nomura Holdings Inc., PNC Financial Services Group Inc., Bank of New York Mellon Corp., Capital One Financial Corp., State Street Corp.

${ }^{10} \mathrm{We}$ control for participation in the previous 2 years to avoid double counting, as the presence of the private banks at time $t$ is included in our outcome variables on the left hand side of equation 1.
} 
nese concessional and non-concessional official financing between 2000 and 2014 (Dreher et al., 2017). Although most of the projects are in African countries and in infrastructure, Chinese official finance targets several countries and many sectors, from health and education to emergency response, agriculture, and social and physical infrastructures, making these data suitable for our purposes. As in the previous exercise, we re-estimate equation 1 including a dummy equal to 1 if the country-sector received a project financed by China in the previous 2 years. Results, reported in Table 6, columns 1-4, show that there is no evidence that past Chinese lending is associated with an increase in syndicated lending, in the number of loans and lenders, and in the average maturity of syndicated loans (if anything, in column 4 the coefficient on the Chinese lending dummy is negative and significant). More important, the estimates of the MDBs mobilization effect are significant and similar in magnitude to those of the baseline (Table 3).

A similar argument could be made for official aid flows, which could signal future growing opportunities, with possible catalytic effects on the private sector. We use OECD (2018) sectoral data on official development assistance from donor countries part of the Development Assistance Committee (DAC) between 1993 and 2015 to construct a dummy equal to 1 if the country-sector received aid flows in the previous 2 years, and zero otherwise. Augmenting our baseline model with this variable leaves again the estimates of the MDBs' mobilization effects statistically significant and qualitatively similar to the baseline. At the same time, we observe significant and positive-although small-effect of aid flows on the number of loans, but no other mobilization effects on volumes, number of lenders and loan maturity (Table 6, columns 5-8). ${ }^{11}$

Sensitivity to outliers. Given that our dependent variables are characterized by a skewed distribution with a large share of zeros, we run several tests to make sure that our results are not driven by outliers. We start by identifying countries or sectors where there are few syndicated loans and exclude them from the analysis. First, we calculate the number of syndicated loans per country in the 1993-2017 period and exclude countries that have fewer than 100 syndicated loans in total. This selection leaves us with a sample of 32 countries. Even though the number of observations in the sample drops significantly, the results—shown in Table A4-are mostly robust: the estimated coefficients on the MDB dummy when the outcome variable is the number of loans are not significantly different from zero (column 1), but the effects on loan size (column 2), banks per loan (column 3) and loan maturity (column 4) are not significantly different from the ones presented

\footnotetext{
${ }^{11}$ These findings are qualitatively similar if we jointly control for the top 10 banks, Chinese lending and sectoral foreign aid; the results not shown for the sake of brevity but are available upon request.
} 
in Table 3. Second, we exclude from the sample sectors with fewer than 1,000 syndicated loans in 1993-2017. We are left with 5 sectors: oil and gas, construction and real estate, manufacturing, infrastructure, and finance. As shown in Table A5, results are mostly not significantly different from Table 3 either. Finally, we combine the previous two exercises and exclude the outliers defined both in terms of countries and of sectors. As it can be seen in Table A6, even though the sample size is about $15 \%$ of the whole sample, results are consistent with the baseline. ${ }^{12}$

Sensitivity to model specification. To ensure that results are not driven by model specification, we also run Monte Carlo Simulations with 1,000 replications. To perform them, we create artificial datasets in which everything is the same, except for the treatment, which is randomly re-assigned to country-sectors-years. The original distribution of the treatment variable is then kept identical. Finally, we estimate equation 1 in each of the 1,000 different samples, producing an averaged estimated cumulative effect and standard errors across the 1,000 replications. Average individual coefficients of interest are also estimated, but we do not report them for the sake of simplicity. Table A7 presents the cumulative effects from $t-2$ to $t$. As expected, cumulative effects are never statistically significant from zero, indicating that the model by itself does not give mobilization effects.

Clustering of standard errors. As a final robustness check, we cluster standard errors at the country-sector level rather than at the country level. In our fixed effects setting, a clustering adjustment is necessary if the treatment assignment mechanism is clustered and if there is heterogeneity in the treatment effects (Abadie et al., 2017). Throughout the paper we have clustered standard errors at the country level, in line with the idea that MDB support is assigned at the country level and that mobilization effects are heterogeneous across countries. However, if the decision to provide MDB syndicated loans is made at the country-sector level, clustering at a more aggregate level gives estimates that are too conservative. As the level at which MDB support is assigned cannot be determined with certainty, we opted for the most conservative approach and clustered at the country level. Table A8 provides a robustness check with standard errors clustered at the country-sector level, in line with MDB support assigned at the country-sector level. Coefficients are more precisely estimated and more likely to be significantly different from zero compared to the baseline results in Table 3 .

\footnotetext{
${ }^{12}$ These tables show the specification with two lags, but results are to robust to the inclusion of one lag only.
} 


\section{Extensions}

\subsection{Direct and Indirect Effects}

The baseline results show that MDB lending attracts resources from private creditors. As discussed in the introduction, the mobilization effect could be the result of two main channels: 1) signaling and demonstration effects, and 2) risk mitigation and better information. In the first case, as investment decisions of the private-sector windows of MDBs are self-financing and their investment model is on commercial terms, their lending could signal to private creditors that there are good investment opportunities in the country-sector that could be exploited. Moreover, the presence of MDBs could attract the private sector because it encourages governments to adopt reforms that can improve macroeconomic stability and the investment climate. Mobilization effects would occur through the second channel when a private lender is encouraged to enter a market that it would have not entered otherwise because of high perceived risks, or due to a lack of knowledge of the counterpart. MDBs can extend their preferred credit status-which means that their loans have been excluded from sovereign debt reschedulings-, have close relationship and a constant engagement with countries, and can monitor closely a project's progress. Hence, partnering with MDBs that can fill the information gaps of private creditors and mitigate political risks is a major opportunity for private lenders (Hainz and Kleimeier, 2012). ${ }^{13}$

Both channels are consistent with our finding that MDBs are among the first banks to enter a country-sector. Hence, the baseline results and the lack of anticipation effects does not help us to discriminate between the two channels. However, looking separately at the mobilization effects through the syndicated loans with and without the loans with MDBs' participation can help disentangle the two channels. The signaling and demonstration effects can attract lenders which will be involved in syndicated loans different from those in which there is the MDB. This is the indirect mobilization effect that we tested in the baseline specification. If the mobilization happens through risk mitigation and information sharing, instead, the private investors would be direct partners of the MDB in the syndicated loan. In fact, the MDB can extend its preferred creditor status to them only. Similarly, the MDB's knowledge and monitoring of the project is beneficial to

\footnotetext{
${ }^{13}$ For instance, "the EBRD's standing as an international institution and, particularly, its preferred creditor status are taken into account in assessing the risks. Loans by international institutions such as the EBRD are, by tradition, excluded from debt reschedulings. Banks participating in loans for which the EBRD remains the lender of record share the benefits of this preferred creditor status" —see https://www.ebrd.com/work-with-us/loan-syndications.html. Similarly, "participants fully benefit from IFC's status as a multilateral development institution. All payments including principal, interest, and fees gain the advantages of IFC's Preferred Creditor Status" — see https://www.ifc.org.
} 
them only, and the risk sharing with the MDB takes place only through the syndicated loan itself. This is the direct mobilization effect.

Thanks to the richness of the data, we are able to observe the total mobilization effects, which include both the direct and indirect mobilization effects. To disentangle indirect from direct effects, we re-estimate equation 1, but the outcome variables now measure total mobilization effects and include also the volume of the loan in which MDBs participate (excluding their share) and the number of private creditors partnering in the loan itself. Results are reported in the first two columns of Table 7, while columns 3 and 4 report only the indirect mobilization effects as estimated in the baseline, where the outcome variables exclude the loans with MDBs' participation. The table reports mobilization effects at time $t$ only to make a clearer comparison between direct and indirect effects, as anything that happens from $t+1$ onward is pure indirect mobilization. Results on total mobilization effects in columns 1 and 2 show that a country-sector with MDB lending experiences a volume of syndicated loans - including both the amount lent by MDB partners (direct mobilization) and the amounts lent through other loans (indirect mobilization)—which is $0.31 \%$ of GDP higher than in country-sectors without MDB participation. ${ }^{14}$ Moreover, in countrysectors with MDBs' participation there are almost 3 more banks, either partnering with the MDB (direct mobilization) or part of other deals (indirect mobilization). Comparing these findings with the indirect mobilization effects as estimated in the baseline (columns 3 and 4, where outcome variables exclude the loans with MDBs participation) shows that the total mobilization effects are larger than the indirect effects, suggesting that both channels—signaling and risk mitigation-are at play.

\subsection{Is There a Crowding Out of Corporate Bonds?}

Our analysis looks exclusively at syndicated lending. In this respect, one may argue that the positive mobilization effects that we have documented so far could be partially (or fully) offset by a reduction in other capital inflows. To address this concern we look at corporate bond issuances, which represent the closest substitute to syndicated loans, as they have similar size and maturity (Altunbaş et al., 2010). Aggregate flows to developing countries highlights that corporate bond and syndicated loans are the largest source of long-term finance in developing countries, given the

\footnotetext{
${ }^{14}$ We cannot isolate direct mobilization effects, as direct mobilization effects will also include part of the indirect effects if an MDB was previously present in the country-sector. Indeed, when we restrict our analysis to 2000-2017, and we control for MDBs' participation in syndicated loans in the country-sector in 1993-1999, we find that MDB mobilization effects are even stronger if MDBs were already present. Findings are robust to reducing the sample period to 2005-2017 and controlling for MDB presence in the country-sector in 1993-2004.
} 
still relatively limited size of equity markets (World Bank, 2015; Cortina et al., 2018).

To test for any substitution effect, we estimate equation 1 taking the number of bond issuances and the total amount of bond issuances (in percent of GDP) in the country-sector pair cs at time $t$ as dependent variables. ${ }^{15}$ Results are reported in Table 8 and show no significant effect in the number of bonds nor in the size of corporate bond financing at the same time and in the two years after MDBs' participation (columns 1 and 5). In the remaining columns we show that results are robust to the inclusion of controls for the presence of the top 10 banks and official development assistance in the previous 2 years. Only when we control for Chinese lending (columns 3 and 7), we observe some marginally significant increase in the number bonds and size of bond financing at $t+1$. The cumulative effects is also positive when considering the number of issuances, while it is not significantly different from zero for the size of inflows. ${ }^{16}$ Overall, the positive sign of all cumulative effects indicate that there is no evidence of crowding out and, if anything, there is some suggestive evidence that MDBs' participation in syndicated lending may also crowd in capital inflows in the corporate bond market.

\subsection{Sector Heterogeneity}

Spillover Effects. Having been reassured that the mobilization effects do not crowd out other sources of firm financing, we exploit the sectoral dimension of the data to explore if there are spillover effects from the lending of MDBs in one sector to another.

If private resources are limited, a sector that attracts investment might crowd out investment to other sectors. Cecchetti and Kharroubi (2015), for example, show that industries that are in competition for financial resources are particularly damaged during credit booms. Specifically, they find that manufacturing sectors that are dependent on external finance can suffer disproportionate reductions in productivity growth. On the contrary, if investment in a sector increases opportunities in other sectors, there might be positive spillovers. Investments to build a road, for example, might attract new workers and the demand for new services or real estate in the location could increase. Lanzalot et al. (2018), for instance, find that the expansion of the Panama Canal supported by MDBs increased private investment in the construction sector, but also in machinery and equipment, in the transport sector, and in real estate.

\footnotetext{
${ }^{15}$ As for the size of syndicated loans, we winsorize the bond size variable at $1 \%$.

${ }^{16}$ Since the sample used to analyze effects on bonds is smaller, we test whether the absence of effects is driven by the sample construction, and re-estimate mobilization effects on syndicated loans in this same sample. Results are robust-see Table A9.
} 
Table 9 reports MDB mobilization effects within the country-sector-year and also mobilization effects of MDB participation in another sector of the same country-year. Controlling for MDB presence in another sector leaves mobilization effects in the sector unaltered. At the same time, MDB participation in another sector does not seem to significantly prevent private resources from flowing into other sectors. On the contrary, when MDBs participate in a sector, there is evidence of positive spillovers on the number of creditors participating in other sectors, which might indicate that the participation of MDBs in a sector might create new opportunities in other sectors too, which, however, are not reflected in the number of loans, size or maturity.

Infrastructure Lending. We also assess whether mobilization effects take place in the infrastructure sector alone. We focus in particular on the latter sector for its relevance for development and for the urgent need of resources that characterizes it (Dobbs et al., 2013; World Bank, 2018). According to UN estimates, total investment in economic infrastructure is currently under $\$ 1$ trillion per year, but will need to reach between \$1.6-2.5 trillion a year over the period 2015-30 (UNCTAD, 2014). The sector can provide relatively high total returns with low correlations to traditional asset classes (e.g. equities, real estate), but it is characterized by high perceived risks (JPMorgan, 2017; Blended Finance Taskforce, 2018). Moreover, given its long-term financing needs, the sector is more vulnerable to scarcity of resources (Chelsky et al., 2013), making the effect of multilateral lending in attracting private flows particularly relevant. Hence, we limit our analysis to a subsample of syndicated loans in infrastructure only (Table 10). Perhaps due to a loss of power, we do not observe any significant effects on the number of loans nor on size. The effect on the number of creditors is similar to our baseline results. Given that investments in infrastructure are long-term, what is perhaps most interesting to note is the larger mobilization effect on maturity: MDB participation in the infrastructure sector of a country increases the average maturity of syndicated loans by 0.81 years, and results are substantial even in the years after.

\subsection{Country Heterogeneity}

The Role of Country Risk. The institutional and regulatory setting is a key factor that is likely to affect the crowding in of private creditors. Analyzing syndicated lending to more than 40 countries, Qian and Strahan (2007) show that strong protection of creditor rights is associated with an increased participation of foreign banks and an expansion of credit supply as firms can borrow at longer-term and lower prices. Looking at syndicated loan pricing in developing countries, 
Boehmer and Megginson (1990) argue that measures of country's solvency, which are associated with higher creditworthiness, significantly decrease loan prices.

To understand whether the creditworthiness of a country affects the mobilization effects of MDBs we look at credit ratings. Credit ratings are an important tool for investors and lenders to make decisions. Being upgraded to investment grade can affect the country's ability to borrow money on the market, as the investment grade rating means that a country is considered by major credit agencies capable and willing to meet its financial obligations fully and in a timely manner. However, if and how credit ratings might affect mobilization effects of MDBs is not clear a priori. On the one hand, it could be easier for MDBs to mobilize capitals in a time where the country enjoys higher ratings because the country itself is already attractive; on the other hand, it could be that exactly when the country is associated with higher risk and struggles to access funding in international bond markets, the presence of MDBs becomes crucial to catalyze additional resources. In line with this argument, Hainz and Kleimeier (2012) document that the participation of MDBs in the loan syndicate helps to mitigate political risk and Gurara et al. (2018) show that the presence of an MDB in the syndicate provides risk mitigation, since it is associated with significantly lower risk premium for companies headquartered in riskier countries. Moreover, if a country is upgraded to investment grade, a larger set of investors can hold its debt, like insurance companies, pension funds or specific mutual funds (Rigobon, 2002). If the latter are substitutes to syndicated loans, the entrance of MDBs in the country-sector might be less effective in attracting loans, as financing need are smaller than before the upgrade.

We employ the investment grade rating provided by Standard \& Poors (S\&P), awarded when a country's long-term foreign currency sovereign credit rating is BBB- or higher. If the rating from S\&P is missing, we replace it with Moody's, for which a country's sovereign debt retains investment grade if Baa3 or higher. ${ }^{17}$ A country that has never been rated by S\&P or Moody's is considered a non-investment grade country.

Table 11 show that cumulative effects from time $t$ to $t+2$ are significantly larger from zero for all outcomes only when countries are rated as investment grade (columns 5-8), whereas for risky countries this is true only for the number of creditors and loan maturity (columns 1-4). These results imply that it is easier for MDBs to mobilize syndicated loans and larger credit flows to less risky countries. However, the evidence on the number of banks per loan and loan maturity suggests that MDBs' participation can help attracting other lender and improve loan terms through

\footnotetext{
${ }^{17}$ We use the Moody's ratings for 240 country-year observations.
} 
risk mitigation. In particular, it is interesting to note that the cumulative mobilization effects on maturity are larger in countries without investment grade rating and, given that in these countries the average maturity of loans is significantly smaller, the effect on loan terms is larger in risky countries.

The Role of Financial Development. The capacity of MDBs to mobilize private credit through syndicated lending could also depend on the degree of financial development in the recipient countries, as a certain degree of market depths, as well as integration in the global financial markets are necessary conditions to gain access to credit syndications. For instance, Godlewski and Weill (2008) show that financial development, banking regulation, and legal institutions are key drivers to explain in the decision to syndicate a loan in emerging markets.

To assess whether mobilization effects differ depending on the financial development of the country, we calculate the average domestic credit to the private sector by banks (in percent of GDP) from the World Bank's World Development Indicators, and we divide countries in more and less financially developed according to the average domestic credit rate being above or below the sample median, respectively. ${ }^{18}$ Table 12 assesses whether the mobilization effects of multilateral lending change with the level of financial development. Results show significantly larger mobilization effects in countries that are more financially developed, where we see significant mobilization effects on size, banks and maturity (columns 1-4). In less financially developed countries instead, most of MDB mobilization effects are nullified, with average maturity as the only exception, confirming that financial development affect the access to loan syndication (columns 5-8).

Zooming in Low-Income and Low-Growth Countries. Finally, we test whether MDBs' mobilization effects are limited to countries that are already attractive to private-sector creditors, or if MDBs can also attract private sector resources in less attractive countries. To this end, we restrict our attention first to a sub-sample of low income countries, as defined by the World Bank ${ }^{19}$, and then to a sub-sample of countries characterized by low growth.

Columns 1-4 in Table 13 show no mobilization effects in low income countries at time $t$, nor at $t+1$. However, two years after MDB participation there is a significant positive increase in the number of loans, in the number of creditors, and in the maturity of loans. However, the magnitude

\footnotetext{
${ }^{18}$ Countries by average domestic credit to the private sector (\% of GDP) are listed in Table A2.

${ }^{19}$ See: https://datahelpdesk.worldbank.org/knowledgebase/articles/906519-world-bank-country-and-lendinggroups. The list of countries in the sub-samples of low income and middle and income countries is reported in Table A3.
} 
of the latter is not enough to make cumulative effects significant. This result might indicate a greater difficulty to mobilize private capital in low income countries, a finding in line with the latest joint report by MDBs on mobilization, where the largest amounts mobilized are found in high income countries, given that most of private investors have little or no interest to take country risk, which is higher in low income countries (World Bank, 2018).

For the second exercise, we divide the sample in two sub-samples of country-year observations according to real GDP growth being below or above the sample median, based on data from the IMF's World Economic Outlook. Results for the low-growth sample are reported in columns 5-8 (Table 13). While there are no significant changes in the number of loans nor lending banks per loan in country-years where GDP growth is low, MDBs' participation is significantly associated with

higher credit. Finally, the maturity of loans consistently increases over the three-year window by around 4 months per year, a sizable increase considering that the average maturity of syndicated loans without MDB support is almost 5.5 years.

Overall, these findings suggest that mobilization effects are less likely to be successful in poor countries, possibly because their higher country risk, which we have shown to be a barrier to attracting private capital. On the contrary, the growth performance seems less likely to be a constraint, a result in line with the idea that MDBs invest and catalyze development financing with a long-term horizon, and are therefore less affected by the business cycle.

\section{Conclusions}

Filling the investment gap to achieve the sustainable development goals is one of the most important development challenges. Official assistance and domestic revenue mobilization could be important options, but they will not be sufficient to fill the gap. Private sector investment will be key to make progresses towards inclusive growth. In this respect, multilateral development banks can play a fundamental role through a stronger engagement to attract additional resources from the private sector.

In this paper we use granular data on syndicated lending to evaluate whether MDBs can mobilize private capital inflows. Our main results indicate that once an MDB enter a country-sector pair through the participation in a loan syndication, the number of total syndicated loans and the associated capital inflows increase. In addition, access to credit improves as the average number of lending banks per loan and the average loan maturity increase too. These effects are economically 
sizable and last over at least up to three years. We also find evidence of indirect and direct mobilization effects, consistent with the fact that MDBs are able to mobilize resources through signaling and demonstration effects, as well as risk mitigation and the provision of better information.

Our results critically indicate that the mobilization effects are not homogeneous across countries. In particular, most of the effects are concentrated in countries which are more economically and financially developed, and have better credit ratings. By contrast, MDB lending is less effective in low-income, less financially developed and risky countries, suggesting that MDBs still face significant challenges to attract private resources especially in countries with larger financing needs. 


\section{References}

Abadie, A., Athey, S., Imbens, G. W., and Wooldridge, J. (2017). When should you adjust standard errors for clustering? Technical report, National Bureau of Economic Research.

Altunbaş, Y., Kara, A., and Marqués-Ibáñez, D. (2010). Large debt financing: Syndicated loans versus corporate bonds. The European Journal of Finance, 16(5):437-458.

Arezki, R., Bolton, P., Peters, S., Samama, F., and Stiglitz, J. (2017). From Global Savings Glut to Financing Infrastructure. Economic Policy, 32(90):221-261.

Basílio, M. S. (2014). The determinants of multilateral development banks' participation in infrastructure projects. Journal of Infrastructure Development, 6(2):83-110.

Bird, G. (2007). The IMF: A Bird's Eye View of Its Role and Operations. Journal of Economic Surveys, 21(4):683-745.

Bird, G. and Rowlands, D. (2007). The imf and the mobilisation of foreign aid. The Journal of Development Studies, 43(5):856-870.

Blended Finance Taskforce (2018). Better Finance; Better World. Consultation Paper.

Boehmer, E. and Megginson, W. L. (1990). Determinants of Secondary Market Prices for Developing Country Syndicated Loans. The Journal of Finance, 45(5):1517-1540.

Bruche, M., Malherbe, F., and Meisenzahl, R. R. (2017). Pipeline Risk in Leveraged Loan Syndication. CEPR Discussion Paper 11956, Center for Economic and Policy Research (CEPR).

Carey, M. and Nini, G. (2007). Is the corporate loan market globally integrated? A pricing puzzle. The Journal of Finance, 62(6):2969-3007.

Carter, P., Van de Sijpe, N., and Calel, R. (2018). The Elusive Quest for Additionality. Working Paper 495, Center for Global Development, Washington DC.

Cecchetti, S. G. and Kharroubi, E. (2015). Why does financial sector growth crowd out real economic growth? Working Paper 490, Bank of International Settlements, Basel.

Chelsky, J., Morel, C., and Kabir, M. (2013). Investment financing in the wake of the crisis: The role of multilateral development banks. World Bank - Economic Premise, (121). 
Corsetti, G., Guimaraes, B., and Roubini, N. (2006). International lending of last resort and moral hazard: A model of IMF's catalytic finance. Journal of Monetary Economics, 53(3):441-471.

Cortina, J. J., Didier, T., and Schmukler, S. (2018). Corporate Borrowing and Debt Maturity: The Effects of Market Access and Crises. Discussion Paper 13008, Center for Economic and Policy Research (CEPR).

Dasgupta, D. and Ratha, D. (2000). What factors appear to drive private capital flows to developing countries? and how does official lending respond? Policy Research Working Paper Series 2392, The World Bank.

Dobbs, R., Pohl, H., Lin, D.-Y., Mischke, J., Garemo, N., Hexter, J., Matzinger, S., Palter, R., and Nanavatty, R. (2013). Infrastructure productivity: how to save 1 trillion a year. McKinsey Global Institute, 88 .

Dreher, A., Fuchs, A., Parks, B., Strange, A. M., and Tierney, M. J. (2017). Aid, China, and growth: Evidence from a new global development finance dataset. Working Paper 46, AidData, Williamsburg, VA.

Dreher, A., Fuchs, A., Parks, B., Strange, A. M., and Tierney, M. J. (2018). Apples and dragon fruits: the determinants of aid and other forms of state financing from China to Africa. International Studies Quarterly, 62(1):182-194.

Eichengreen, B., Kletzer, K., and Mody, A. (2006). The imf in a world of private capital markets. Journal of Banking $\mathcal{E}$ Finance, 30(5):1335-1357.

Eichengreen, B. J. and Mody, A. (2000). What Explains Changing Spreads on Emerging Market Debt? In Capital Flows and the Emerging Economies: Theory, Evidence, and Controversies, pages 107-136. National Bureau of Economic Research.

Eichengreen, B. J. and Mody, A. (2001). Bail-Ins, Bailouts, and Borrowing Costs. IMF Staff Papers, 47:155-187.

Erce, A. and Riera-Crichton, D. (2015). Catalytic IMF? A Gross Flows Approach. Working Paper 9, European Stability Mechanism, Luxembourg.

Galindo, A. J. and Panizza, U. (2018). The cyclicality of international public sector borrowing in developing countries: Does the lender matter? World Development, 112(119-135). 
Giannini, C. and Cottarelli, M. C. (2002). Bedfellows, hostages, or perfect strangers? Global capital markets and the catalytic effect of IMF crisis lending. Working Paper 02-193, International Monetary Fund, Washington DC.

Godlewski, C. J. and Weill, L. (2008). Syndicated loans in emerging markets. Emerging Markets Review, 9(3):206-219.

Group of Twenty (2018). Coordination Between the International Monetary Fund and Multilateral Development Banks on Policy-Based Lending: Update on the Implementation of the G20 Principles. Note.

Gurara, D., Presbitero, A. F., and Sarmiento, M. (2018). Borrowing costs and the role of multilateral development banks: Evidence from cross-border syndicated bank lending. IMF Working Paper 263, International Monetary Fund, Washington D.C.

Gurría, J. A., Volcker, P. A., and Birdsall, N. (2001). The Role of the Multilateral Development Banks in Emerging Market Economies: Findings of the Commission on the Role of the MDBs in Emerging Markets. Carnegie endowment for international Peace.

Hainz, C. and Kleimeier, S. (2012). Political risk, project finance, and the participation of development banks in syndicated lending. Journal of Financial Intermediation, 21(2):287-314.

Humphrey, C. and Michaelowa, K. (2013). Shopping for Development: Multilateral Lending, Shareholder Composition and Borrower Preferences. World Development, 44:142-155.

Inter-American Development Bank Group (2018). Development Effectiveness Overview (DEO). Annual Report.

JPMorgan (2017). The Infrastructure Moment; Insights and Research. Investment Insights.

Kidwelly, P., editor (2017). Principles of MDBs' strategy for crowding-in Private Sector Finance for growth and sustainable development. G20 International Financial Architecture Working Group.

Lanzalot, M. L., Maffioli, A., Stucchi, R., and Yanez-Pagans, P. (2018). Infrastructure investments and private sector catalyzation: The case of the panama canal expansion. Technical Note 9, Inter-American Investment Corporation, Washington DC.

Miller, S. (2006). A syndicated loan primer. Standard \& Poor's Guide to The Loan Market, New York. 
Mody, A. and Saravia, D. (2006). Catalysing private capital flows: Do IMF programmes work as commitment devices? Economic Journal, 116(513):843-867.

Morris, S. and Shin, H. S. (2006). Catalytic finance: When does it work? Journal of International Economics, 70(1):161-177.

Nini, G. P. (2004). The Value of Financial Intermediaries: Empirical Evidence from Syndicated Loans to Emerging Market Borrowers. International Finance Discussion Paper 820, Board of Governors of the Federal Reserve System.

OECD (2018). Oda by sector (indicator). doi: 10.1787/a5a1f674-en (Accessed on 29 November 2018).

Pereira dos Santos, P. and Kearney, M. (2018). Multilateral Development Banks' risk mitigation instruments for infrastructure investment. IDB Technical Note 1358, Inter-American Development Bank.

Qian, J. and Strahan, P. E. (2007). How Laws and Institutions Shape Financial Contracts: The Case of Bank Loans. The Journal of Finance, 62(6):2803-2834.

Ratha, D. (2001). Complementary Between Multilateral Lending and Private Flows to Developing Countries: Some Empirical Results. Policy Research Working Paper 2746, The World Bank.

Rigobon, R. (2002). The curse of non-investment grade countries. Journal of Development Economics, 69(2):423-449.

Rodrik, D. (1995). Why is there multilateral lending? NBER Working Papers 5160, National Bureau of Economic Research.

Shi, L. (2017). Masala bond program-nurturing a local currency bond market.

Swaroop, V. and Devarajan, S. (1999). The implications of foreign aid fungibility for development assistance. The World Bank.

UNCTAD (2014). World Investment Report 2014. Investing in the SDGs: An Action Plan. United Nations Conference on Trade and Development, Geneva.

United Nations (2015). Addis Ababa Action Agenda of the Third International Conference on Financing for Development. New York. United Nations. 
World Bank (2015). Global Financial Development Report 2015-2016: Long-Term Finance. The World Bank, Washington DC.

World Bank (2018). Mobilization of private finance by multilateral development banks and development finance institutions 2017. Technical report, Washington, D.C. : World Bank Group. 


\section{A Figures}

Figure 1: Number of Syndicated Loans and Share with MDB Support by Country, 1993-2017

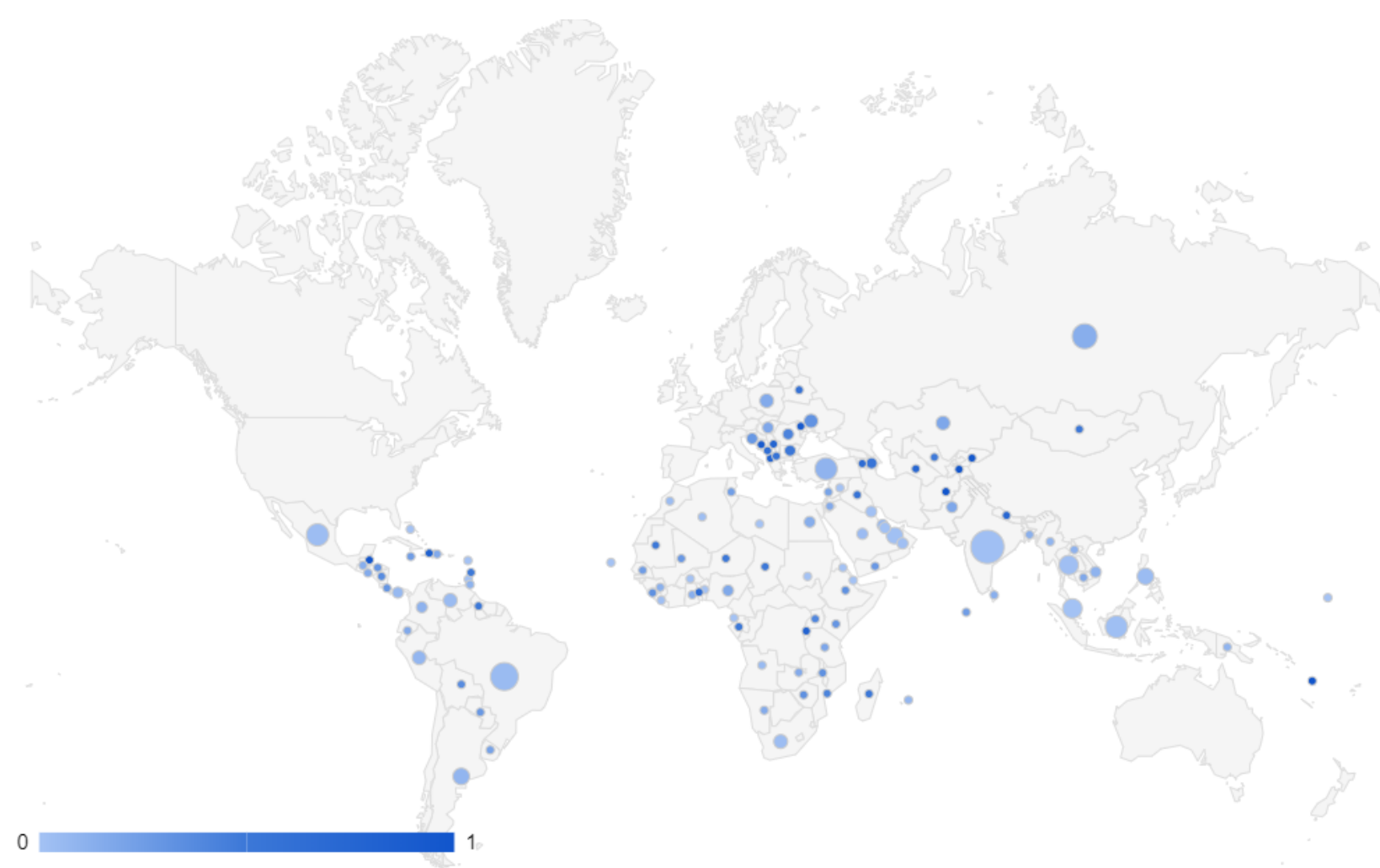

Notes: The bubbles in the map represent the number of syndicated loans by country in 1993-2017. The area represents the number of total syndicated loans in the period: the larger the bubble, the more syndicated loans. The color represents the share of syndicated loans supported by at least one MDB in the period: the darker the blue, the more the syndicated loans receive MDB support. 
Figure 2: Number of Syndicated Loans

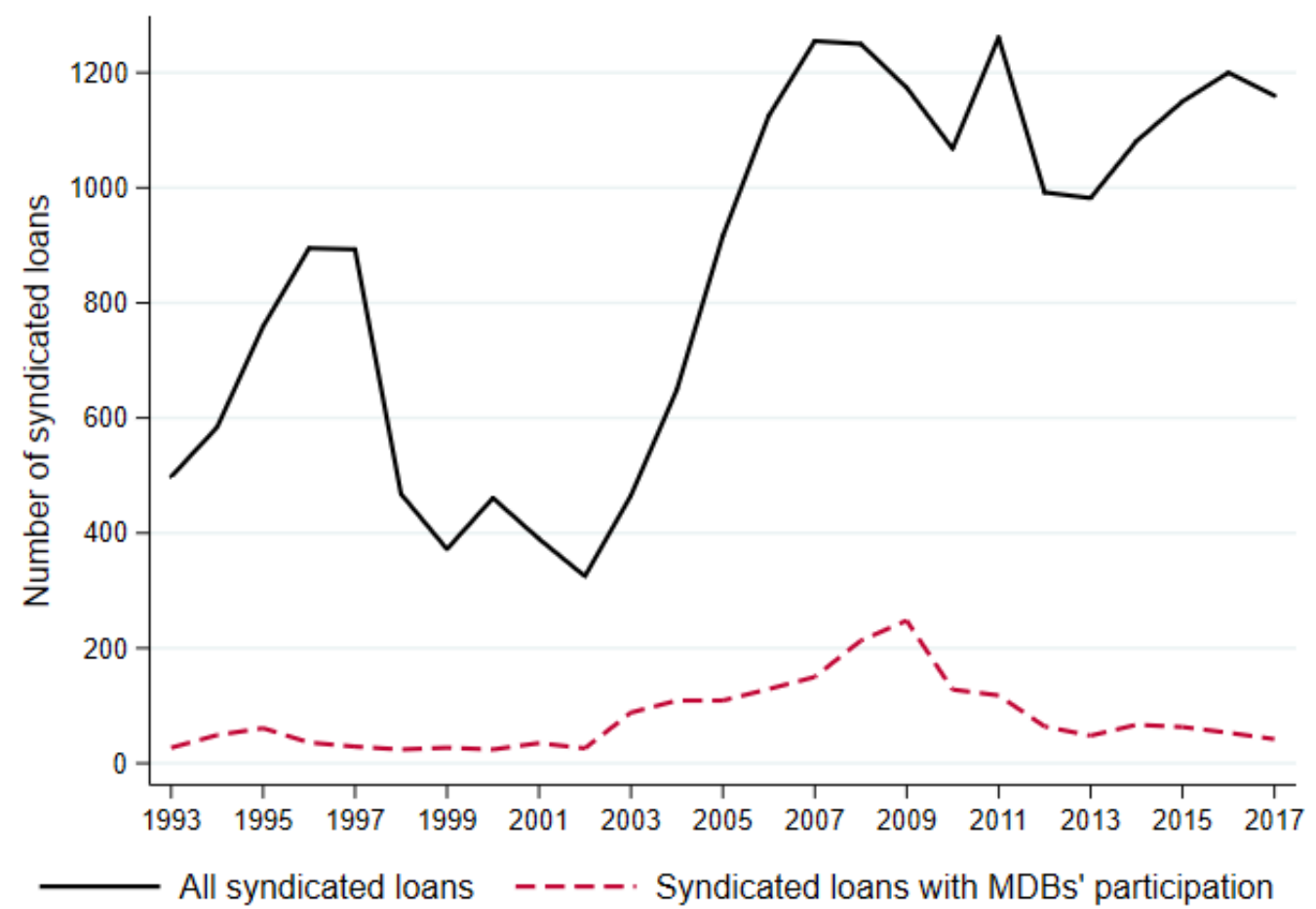

Notes: The chart shows the trend in total number of syndicated loans over time. Source: Dealogic Loan Analytics. 


\section{B Tables}

Table 1: Summary Statistics of Syndicated Loans

\begin{tabular}{lccllc}
\hline & Mean & SD & Min & Max & N \\
\cline { 2 - 6 } & & & & & \\
Panel A. All Syndicated Loans & & & & & \\
\hline Size (\% GDP) & 0.108 & 0.319 & 0.001 & 4.295 & 21,164 \\
Number of participating banks & 6.153 & 7.498 & 1 & 80 & 21,373 \\
Maturity (years) & 5.458 & 4.476 & 0.083 & 35.083 & 18,603 \\
Panel B. Syndicated Loans with MDB Participation & & & & & \\
\hline Size (\% GDP) & 0.169 & 0.403 & 0.001 & 3.938 & 1,946 \\
Number of participating banks & 4.487 & 5.976 & 1 & 59 & 1,967 \\
Maturity (years) & 7.489 & 4.499 & 0.2 & 30 & 1,111 \\
\hline
\end{tabular}

Notes: The table provides summary statistics for the main outcome variables in the analysis: size of syndicated loans (\% of GDP), number of banks participating in syndicated loans, and average weighted maturity (in years, averaged across tranches, where weights are the relatives sizes of the tranches) of syndicated loans. Panel A refers to the full sample of syndicated loans at the individual level. Panel B refers only to those syndicated loans where there is at least one MDB that supports a syndicated loan.

Table 2: Summary Statistics in the Aggregate Data

\begin{tabular}{lllllll}
\hline Mean & SD & Min & Max & N
\end{tabular}

Panel A. Syndicates Loans

\begin{tabular}{llllll}
\hline Number of Loans & 0.737 & 4.518 & 0 & 188 & 26,325 \\
Size (\% GDP) & 0.109 & 0.693 & 0 & 41.514 & 26,325 \\
$\quad$ Size w /o Loan w /MDB (\% GDP) & 0.101 & 0.672 & 0 & 41.514 & 26,325 \\
Banks & 1.474 & 5.185 & 0 & 80 & 26,325 \\
$\quad$ Banks w/o MDB partners & 1.562 & 5.309 & 0 & 80 & 26,325 \\
Maturity (years) & 0.724 & 2.174 & 0 & 35 & 26,096 \\
& & & & & \\
Panel B. Corporate Bonds & & & & & \\
\hline Number of Bonds & 1.245 & 8.801 & 0 & 336 & 15,075 \\
Bond Size (\% GDP) & 0.037 & 0.18 & 0 & 6.187 & 15,075 \\
\hline
\end{tabular}

Notes: The table provides summary statistics for the main outcome variables in the analysis in the full sample of countrysector-years. Panel A reports summary statistics for number of loans, size of syndicated loans (\% of GDP) including the amount brought by MDB partners, size of syndicated loans (\% of GDP) excluding the amount brought by MDB partners, average banks per loan including MDB partners, average banks per loan excluding MDB partners, and maturity of syndicated loans (in years) in country-sector-years. Size outcomes are winsorized at the $1 \%$ level. Maturity is the average weighted maturity (averaged across tranches, where weights are the relatives sizes of the tranches) of syndicated loans. Panel B reports summary statistics for number of corporate bonds and size of bonds ( $\%$ of GDP) in country-sector-years. Size is winsorized at the $1 \%$ level. 
Table 3: MDB Mobilization Effects

\begin{tabular}{|c|c|c|c|c|}
\hline & $\begin{array}{l}\text { Number } \\
\text { of loans } \\
(1)\end{array}$ & $\begin{array}{l}\text { Size (\% GDP) } \\
\text { (2) }\end{array}$ & $\begin{array}{l}\text { Banks } \\
\text { (3) }\end{array}$ & $\begin{array}{l}\text { Maturity } \\
\text { (4) }\end{array}$ \\
\hline $\mathrm{MDB}_{\mathrm{cs}, \mathrm{t}}$ & $\begin{array}{l}0.8514 \\
(0.535)\end{array}$ & $\begin{array}{l}0.0724^{* * *} \\
(0.022)\end{array}$ & $\begin{array}{l}0.5475^{* *} \\
(0.223)\end{array}$ & $\begin{array}{l}0.3581^{* * *} \\
(0.093)\end{array}$ \\
\hline $\mathrm{MDB}_{\mathrm{cs}, \mathrm{t}-1}$ & $\begin{array}{l}0.8166^{*} \\
(0.453)\end{array}$ & $\begin{array}{l}0.0293 \\
(0.025)\end{array}$ & $\begin{array}{l}0.7406^{* * *} \\
(0.219)\end{array}$ & $\begin{array}{l}0.1413 \\
(0.103)\end{array}$ \\
\hline $\mathrm{MDB}_{\mathrm{cs}, \mathrm{t}-2}$ & $\begin{array}{l}0.7803^{*} \\
(0.439)\end{array}$ & $\begin{array}{l}0.0561^{* * *} \\
(0.019)\end{array}$ & $\begin{array}{l}0.6865^{* *} \\
(0.270)\end{array}$ & $\begin{array}{l}0.2908^{* * *} \\
(0.092)\end{array}$ \\
\hline $\begin{array}{l}\sum_{k=0}^{2} M D B_{\mathrm{cs}, \mathrm{t}-\mathrm{k}} \\
\text { Wald test : } p \text { value }\end{array}$ & $2.448^{*}$ & $0.158^{* * *}$ & $1.975^{* * *}$ & $0.790^{* * *}$ \\
\hline Observations & 24,219 & 24,219 & 24,219 & 24,023 \\
\hline R-squared & 0.607 & 0.381 & 0.659 & 0.522 \\
\hline Sector-country FE & Yes & Yes & Yes & Yes \\
\hline Sector-year FE & Yes & Yes & Yes & Yes \\
\hline Country-year FE & Yes & Yes & Yes & Yes \\
\hline Average MDB & 0.0483 & 0.0483 & 0.0483 & 0.0477 \\
\hline Average Number of Loans & 0.760 & & & \\
\hline Average Size (\%GDP) & & 0.105 & & \\
\hline Average Banks & & & 1.526 & \\
\hline Average Maturity & & & & 0.755 \\
\hline
\end{tabular}

Notes: The table presents estimates of equation 1 . The dependent variables are number of loans (column 1), size of syndicated loans (\% of GDP) (column 2), banks per loan (column 3), and maturity of syndicated loans (in years) (column 4) in the country-sector-year. $\mathrm{MDB}_{\mathrm{cs}, \mathrm{t}}$ is a dummy equal to 1 if there is at least one MDB providing a syndicated loan in country-sector $c s$ at time $t$. The cumulative effect of $\mathrm{MDB}_{\mathrm{cs}, \mathrm{t}}$ between year $t-2$ and $t$, and the the $\mathrm{p}$-value of a Wald test showing its significance, are also reported. The last rows show the averages of $\mathrm{MDB}_{\mathrm{cs}, \mathrm{t}}$ and the outcome variables in the estimation. Standard errors clustered at country level are in parentheses: ${ }^{*} p<0.1,{ }^{* *} p<0.05,{ }^{* * *} p<0.01$. 
Table 4: Controlling for Anticipation Effects

\begin{tabular}{|c|c|c|c|c|}
\hline & $\begin{array}{l}\text { Number } \\
\text { of loans } \\
(1)\end{array}$ & $\begin{array}{l}\text { Size (\% GDP) } \\
(2)\end{array}$ & $\begin{array}{l}\text { Banks } \\
\text { (3) }\end{array}$ & $\begin{array}{l}\text { Maturity } \\
\text { (4) }\end{array}$ \\
\hline $\mathrm{MDB}_{\mathrm{cs}, \mathrm{t}}$ & $\begin{array}{l}0.8176^{* *} \\
(0.373)\end{array}$ & $\begin{array}{l}0.0703^{* * *} \\
(0.025)\end{array}$ & $\begin{array}{l}0.5065^{* *} \\
(0.239)\end{array}$ & $\begin{array}{l}0.3366^{* * *} \\
(0.102)\end{array}$ \\
\hline $\mathrm{MDB}_{\mathrm{cs}, \mathrm{t}-1}$ & $\begin{array}{l}0.9013^{* * *} \\
(0.296)\end{array}$ & $\begin{array}{l}0.0245 \\
(0.027)\end{array}$ & $\begin{array}{l}0.6947^{* * *} \\
(0.220)\end{array}$ & $\begin{array}{l}0.0781 \\
(0.107)\end{array}$ \\
\hline $\mathrm{MDB}_{\mathrm{cs}, \mathrm{t}-2}$ & $\begin{array}{l}0.8960^{* * *} \\
(0.308)\end{array}$ & $\begin{array}{l}0.0563^{* * *} \\
(0.020)\end{array}$ & $\begin{array}{l}0.6318^{* *} \\
(0.277)\end{array}$ & $\begin{array}{l}0.2038^{* *} \\
(0.093)\end{array}$ \\
\hline $\mathrm{MDB}_{\mathrm{cs}, \mathrm{t}+1}$ & $\begin{array}{l}0.4407 \\
(0.379)\end{array}$ & $\begin{array}{l}0.0410 \\
(0.027)\end{array}$ & $\begin{array}{l}0.3179 \\
(0.233)\end{array}$ & $\begin{array}{l}0.1260 \\
(0.104)\end{array}$ \\
\hline $\mathrm{MDB}_{\mathrm{cs}, \mathrm{t}+2}$ & $\begin{array}{l}0.3091 \\
(0.253)\end{array}$ & $\begin{array}{l}0.0602 \\
(0.052)\end{array}$ & $\begin{array}{l}0.3627 \\
(0.268)\end{array}$ & $\begin{array}{l}0.1634 \\
(0.100)\end{array}$ \\
\hline Observations & 22,113 & 22,113 & 22,113 & 21,938 \\
\hline R-squared & 0.670 & 0.378 & 0.664 & 0.523 \\
\hline Sector-country FE & Yes & Yes & Yes & Yes \\
\hline Sector-year FE & Yes & Yes & Yes & Yes \\
\hline Country-year FE & Yes & Yes & Yes & Yes \\
\hline Average MDB & 0.049 & 0.049 & 0.049 & 0.049 \\
\hline Average Number of Loans & 0.730 & & & \\
\hline Average Size (\% GDP) & & 0.105 & & \\
\hline Average Banks & & & 1.545 & \\
\hline Average Maturity & & & & 0.738 \\
\hline
\end{tabular}

Notes: The table presents estimates of equation 2. The dependent variables are number of loans (column 1), size of syndicated loans (\% of GDP) (column 2), banks per loan (column 3), and maturity of syndicated loans (in years) (column 4) in the country-sector-year. $\mathrm{MDB}_{\mathrm{cs}, \mathrm{t}}$ is a dummy equal to 1 if there is at least one MDB providing a syndicated loan in country-sector $c s$ at time $t$. The last rows show the averages of $\mathrm{MDB}_{\mathrm{cs}, \mathrm{t}}$ and the outcome variables in the estimation. Standard errors clustered at country level are in parentheses: ${ }^{*} \mathrm{p}<0.1,{ }^{* *} \mathrm{p}<0.05,{ }^{* * *} \mathrm{p}<0.01$. 
Table 5: Mobilization Effects Controlling for Top 10 Banks

\begin{tabular}{|c|c|c|c|c|}
\hline & $\begin{array}{l}\text { Number } \\
\text { of loans } \\
(1)\end{array}$ & $\begin{array}{l}\text { Size (\% GDP) } \\
(2)\end{array}$ & $\begin{array}{l}\text { Banks } \\
\text { (3) }\end{array}$ & $\begin{array}{l}\text { Maturity } \\
\text { (4) }\end{array}$ \\
\hline $\mathrm{MDB}_{\mathrm{cs}, \mathrm{t}}$ & $\begin{array}{l}0.8491 \\
(0.536)\end{array}$ & $\begin{array}{l}0.0705^{* * *} \\
(0.022)\end{array}$ & $\begin{array}{l}0.5303^{* *} \\
(0.214)\end{array}$ & $\begin{array}{l}0.3551^{* * *} \\
(0.093)\end{array}$ \\
\hline $\mathrm{MDB}_{\mathrm{cs}, \mathrm{t}-1}$ & $\begin{array}{l}0.8058^{*} \\
(0.460)\end{array}$ & $\begin{array}{l}0.0207 \\
(0.025)\end{array}$ & $\begin{array}{l}0.6603^{* * *} \\
(0.217)\end{array}$ & $\begin{array}{l}0.1272 \\
(0.102)\end{array}$ \\
\hline $\mathrm{MDB}_{\mathrm{cs}, \mathrm{t}-2}$ & $\begin{array}{l}0.7680^{*} \\
(0.451)\end{array}$ & $\begin{array}{l}0.0463^{* *} \\
(0.020)\end{array}$ & $\begin{array}{l}0.5952^{* *} \\
(0.264)\end{array}$ & $\begin{array}{l}0.2753^{* * * *} \\
(0.092)\end{array}$ \\
\hline Top 10 Banks & $\begin{array}{l}0.1629 \\
(0.321)\end{array}$ & $\begin{array}{l}0.1290^{* * *} \\
(0.044)\end{array}$ & $\begin{array}{l}1.2066^{* * *} \\
(0.265)\end{array}$ & $\begin{array}{l}0.2143^{*} \\
(0.109)\end{array}$ \\
\hline $\begin{array}{l}\sum_{k=0}^{2} M D B_{\mathrm{cs}, \mathrm{t}-\mathrm{k}} \\
\text { Wald test : } p \text { value }\end{array}$ & $\begin{array}{l}2.423^{*} \\
0.0915\end{array}$ & $0.138^{* *}$ & $\begin{array}{l}1.786^{* * *} \\
0.00352\end{array}$ & $\begin{array}{l}0.758^{* * *} \\
3.83 \mathrm{e}-06\end{array}$ \\
\hline Observations & 24,219 & 24,219 & 24,219 & 24,023 \\
\hline R-squared & 0.607 & 0.382 & 0.661 & 0.523 \\
\hline Sector-country FE & Yes & Yes & Yes & Yes \\
\hline Sector-year FE & Yes & Yes & Yes & Yes \\
\hline Country-year FE & Yes & Yes & Yes & Yes \\
\hline Average MDB & 0.0483 & 0.0483 & 0.0483 & 0.0477 \\
\hline Average Number of Loans & 0.760 & & & \\
\hline Average Size (\%GDP) & & 0.105 & & \\
\hline Average Banks & & & 1.526 & \\
\hline Average Maturity & & & & 0.755 \\
\hline
\end{tabular}

Notes: The table presents estimates of equation 1 controlling for the top 10 banks according to S\&P. The dependent variables are number of loans (column 1), size of syndicated loans (\% of GDP) (column 2), banks per loan (column 3), and maturity of syndicated loans (in years) (column 4) in the country-sector-year. $\mathrm{MDB}_{\mathrm{cs}, \mathrm{t}}$ is a dummy equal to 1 if there is at least one MDB providing a syndicated loan in country-sector $c s$ at time $t$. To control for the top 10 banks, we include a dummy equal to 1 if at least 1 of the top banks was present in the country-sector in the previous 2 years. The cumulative effect of $\mathrm{MDB}_{\mathrm{cs}, \mathrm{t}}$ between year $t-2$ and $t$, and the the p-value of a Wald test showing its significance, are also reported. The last rows show the averages of $\mathrm{MDB}_{\mathrm{cs}, \mathrm{t}}$ and the outcome variables in the estimation. Standard errors clustered at country level are in parentheses, ${ }^{*} p<0.1,{ }^{* *} p<0.05,{ }^{* * *} p<0.01$ 
Table 6: Mobilization Effects Controlling for Chinese Lending and Aid Flows

\begin{tabular}{|c|c|c|c|c|c|c|c|c|}
\hline & $\begin{array}{l}\text { Number } \\
\text { of loans } \\
(1)\end{array}$ & $\begin{array}{l}\text { Size (\%GDP) } \\
(2)\end{array}$ & $\begin{array}{l}\text { Banks } \\
\text { (3) }\end{array}$ & $\begin{array}{l}\text { Maturity } \\
\text { (4) }\end{array}$ & $\begin{array}{l}\text { Number } \\
\text { of loans } \\
(5)\end{array}$ & $\begin{array}{l}\text { Size (\%GDP) } \\
(6)\end{array}$ & $\begin{array}{l}\text { Banks } \\
\text { (7) }\end{array}$ & $\begin{array}{l}\text { Maturity } \\
(8)\end{array}$ \\
\hline $\mathrm{MDB}_{\mathrm{cs}, \mathrm{t}}$ & $\begin{array}{l}0.5779^{* * *} \\
(0.178)\end{array}$ & $\begin{array}{l}0.0657 \\
(0.044)\end{array}$ & $\begin{array}{l}0.7655^{* *} \\
(0.296)\end{array}$ & $\begin{array}{l}0.3630^{* * *} \\
(0.109)\end{array}$ & $\begin{array}{l}0.9670^{* *} \\
(0.455)\end{array}$ & $\begin{array}{l}0.0826^{* * * *} \\
(0.029)\end{array}$ & $\begin{array}{l}0.5872^{* *} \\
(0.281)\end{array}$ & $\begin{array}{l}0.3945^{* * *} \\
(0.113)\end{array}$ \\
\hline $\mathrm{MDB}_{\mathrm{cs}, \mathrm{t}-1}$ & $\begin{array}{l}0.8569^{* * *} \\
(0.232)\end{array}$ & $\begin{array}{l}0.0482 \\
(0.041)\end{array}$ & $\begin{array}{l}0.9972^{* * * *} \\
(0.292)\end{array}$ & $\begin{array}{l}0.1342 \\
(0.126)\end{array}$ & $\begin{array}{l}0.9391^{* * * *} \\
(0.347)\end{array}$ & $\begin{array}{l}0.0163 \\
(0.030)\end{array}$ & $\begin{array}{l}0.5686^{* *} \\
(0.240)\end{array}$ & $\begin{array}{l}0.0671 \\
(0.119)\end{array}$ \\
\hline $\mathrm{MDB}_{\mathrm{cs}, \mathrm{t}-2}$ & $\begin{array}{l}0.8006^{* *} \\
(0.330)\end{array}$ & $\begin{array}{l}0.0653^{* *} \\
(0.028)\end{array}$ & $\begin{array}{l}0.7380^{* *} \\
(0.288)\end{array}$ & $\begin{array}{l}0.1748^{*} \\
(0.100)\end{array}$ & $\begin{array}{l}0.9420^{* * * *} \\
(0.350)\end{array}$ & $\begin{array}{l}0.0512^{* *} \\
(0.021)\end{array}$ & $\begin{array}{l}0.4228 \\
(0.299)\end{array}$ & $\begin{array}{l}0.1907^{*} \\
(0.099)\end{array}$ \\
\hline Chinese lending & $\begin{array}{l}0.0039 \\
(0.055)\end{array}$ & $\begin{array}{l}-0.0170 \\
(0.039)\end{array}$ & $\begin{array}{l}0.0807 \\
(0.116)\end{array}$ & $\begin{array}{l}-0.1576^{* *} \\
(0.064)\end{array}$ & & & & \\
\hline ODA & & & & & $\begin{array}{l}0.0997^{* *} \\
(0.049)\end{array}$ & $\begin{array}{l}-0.0202 \\
(0.016)\end{array}$ & $\begin{array}{l}-0.0925 \\
(0.144)\end{array}$ & $\begin{array}{l}-0.0381 \\
(0.050)\end{array}$ \\
\hline $\begin{array}{l}\sum_{k=0}^{2} M D B_{\text {cst }-\mathrm{k}} \\
\text { Wald test : } p \text { value }\end{array}$ & $2.235^{* * *}$ & $0.179^{*}$ & $2.501^{* * *}$ & $0.672^{* * *}$ & $2.848^{* *}$ & $0.150^{* *}$ & $1.579^{* *}$ & $0.652^{* * *}$ \\
\hline Observations & 11,934 & 11,934 & 11,934 & 11,854 & 21,168 & 21,168 & 21,168 & 21,007 \\
\hline R-squared & 0.753 & 0.413 & 0.721 & 0.567 & 0.672 & 0.378 & 0.661 & 0.522 \\
\hline Sector-country FE & Yes & Yes & Yes & Yes & Yes & Yes & Yes & Yes \\
\hline Sector-year FE & Yes & Yes & Yes & Yes & Yes & Yes & Yes & Yes \\
\hline Country-year FE & Yes & Yes & Yes & Yes & Yes & Yes & Yes & Yes \\
\hline Average MDB & 0.0631 & 0.0631 & 0.0631 & 0.0623 & 0.0425 & 0.0425 & 0.0425 & 0.0420 \\
\hline Average Number of Loans & 0.855 & & & & 0.670 & & & \\
\hline Average Size (\%GDP) & & 0.104 & & & & 0.104 & & \\
\hline Average Banks & & & 1.522 & & & & 1.415 & \\
\hline Average Maturity & & & & 0.790 & & & & 0.693 \\
\hline
\end{tabular}

Notes: The table presents estimates of equation 1 controlling for Chinese lending (columns 1-4) and aid flows (columns 5-8). The dependent variables are number of loans, size of syndicated loans (\% of GDP), number of banks per loan, and maturity of syndicated loans (in years) in the country-sector-year. $\mathrm{MDB}_{\mathrm{cs}, \mathrm{t}}$ is a dummy equal to 1 if there is at least one MDB providing a syndicated loan in country-sector cs at time $t$. To control for Chinese official financing and official development assistance (ODA), we include a dummy equal to 1 if the country-sector received them in the previous 2 years. The cumulative effect of MDB $\mathrm{cs}_{\mathrm{s}, \mathrm{t}}$ between year $t-2$ and $t$, and the the p-value of a Wald test showing its significance, are also reported. The last rows show the averages of MDB $\mathrm{cs}_{\mathrm{c}, \mathrm{t}}$ and the outcome variables in the estimation. Standard errors clustered at country level are in parentheses, ${ }^{*} p<0.1,{ }^{* *} p<0.05$, ${ }^{* * *} p<0.01$. Sources: AidData (Dreher et al., 2017) and OECD (2018). 
Table 7: Total Mobilization Effects

\begin{tabular}{|c|c|c|c|c|}
\hline \multirow[b]{3}{*}{$\mathrm{MDB}_{\mathrm{cs}, \mathrm{t}}$} & \multicolumn{2}{|c|}{ Direct + Indirect Effects } & \multicolumn{2}{|c|}{ Indirect Effects } \\
\hline & $\begin{array}{l}\text { Size (\%GDP) } \\
\text { including } \\
\text { MDB loan } \\
\text { (1) }\end{array}$ & $\begin{array}{l}\text { Banks } \\
\text { including } \\
\text { MDB loan } \\
\text { (2) }\end{array}$ & $\begin{array}{l}\text { Size (\%GDP) } \\
\text { excluding } \\
\text { MDB loan } \\
\text { (3) }\end{array}$ & $\begin{array}{l}\text { Banks } \\
\text { excluding } \\
\text { MDB loan } \\
\text { (4) }\end{array}$ \\
\hline & $\begin{array}{l}0.3107^{* * *} \\
(0.044)\end{array}$ & $\begin{array}{l}2.8218^{* * *} \\
(0.281)\end{array}$ & $\begin{array}{l}0.0785^{* * *} \\
(0.024)\end{array}$ & $\begin{array}{l}0.6971^{* * *} \\
(0.230)\end{array}$ \\
\hline Observations & 26,325 & 26,325 & 26,325 & 26,325 \\
\hline R-squared & 0.372 & 0.653 & 0.367 & 0.647 \\
\hline Sector-country FE & Yes & Yes & Yes & Yes \\
\hline Sector-year FE & Yes & Yes & Yes & Yes \\
\hline Country-year FE & Yes & Yes & Yes & Yes \\
\hline Average MDB & 0.0467 & 0.0467 & 0.0467 & 0.0467 \\
\hline Average Size (\% GDP) & 0.109 & & 0.101 & \\
\hline Average Banks & & 1.562 & & 1.474 \\
\hline
\end{tabular}

Notes: The table presents estimates of equation 1, without additional lags of $\mathrm{MDB}_{\mathrm{cs}, \mathrm{t}}$. Columns 1-2 report total mobilization effects (direct + indirect); columns 3-4 report indirect mobilization effects only. The dependent variables are size of syndicated loans (\% of GDP) and number of banks per loan in the country-sector-year. In columns (1)-(2) the outcome variables include the amount lent by MDBs' partners and the number of those partners, respectively. In columns (3)(4) the outcome variables exclude the amount brought by MDBs' partners and the number of the banks. $\mathrm{MDB}_{\mathrm{cs}, \mathrm{t}}$ is a dummy equal to 1 if there is at least one MDB providing a syndicated loan in country-sector cs at time $t$. The last rows show the averages of $\mathrm{MDB}_{\mathrm{cs}, \mathrm{t}}$ and the outcome variables in the estimation. Standard errors clustered at country level are in parentheses: ${ }^{*} \mathrm{p}<0.1,{ }^{* *} \mathrm{p}<0.05,{ }^{* * *} \mathrm{p}<0.01$. 
Table 8: Effects on Bonds

\begin{tabular}{|c|c|c|c|c|c|c|c|c|}
\hline & \multicolumn{4}{|c|}{ Number of Bonds } & \multicolumn{4}{|c|}{ Bond Size (\% GDP) } \\
\hline & (1) & $(2)$ & (3) & $(4)$ & (5) & $(6)$ & $(7)$ & $(8)$ \\
\hline $\mathrm{MDB}_{\mathrm{cs}, \mathrm{t}}$ & $\begin{array}{l}0.3260 \\
(0.608)\end{array}$ & $\begin{array}{l}0.3147 \\
(0.597)\end{array}$ & $\begin{array}{l}1.3724 \\
(1.045)\end{array}$ & $\begin{array}{l}0.5797 \\
(0.777)\end{array}$ & $\begin{array}{l}0.0125 \\
(0.013)\end{array}$ & $\begin{array}{l}0.0122 \\
(0.013)\end{array}$ & $\begin{array}{l}0.0271 \\
(0.023)\end{array}$ & $\begin{array}{l}0.0129 \\
(0.017)\end{array}$ \\
\hline $\mathrm{MDB}_{\mathrm{cs}, \mathrm{t}-1}$ & $\begin{array}{l}0.3702 \\
(0.427)\end{array}$ & $\begin{array}{l}0.3249 \\
(0.411)\end{array}$ & $\begin{array}{l}1.1752^{*} \\
(0.643)\end{array}$ & $\begin{array}{l}0.4984 \\
(0.470)\end{array}$ & $\begin{array}{l}0.0153 \\
(0.013)\end{array}$ & $\begin{array}{l}0.0139 \\
(0.012)\end{array}$ & $\begin{array}{l}0.0350^{*} \\
(0.018)\end{array}$ & $\begin{array}{l}0.0146 \\
(0.016)\end{array}$ \\
\hline $\mathrm{MDB}_{\mathrm{cs}, \mathrm{t}-2}$ & $\begin{array}{l}-0.1260 \\
(0.593)\end{array}$ & $\begin{array}{l}-0.1765 \\
(0.627)\end{array}$ & $\begin{array}{l}-0.1503 \\
(0.671)\end{array}$ & $\begin{array}{c}-0.4550 \\
(0.753)\end{array}$ & $\begin{array}{l}0.0143 \\
(0.014)\end{array}$ & $\begin{array}{l}0.0127 \\
(0.014)\end{array}$ & $\begin{array}{l}0.0237 \\
(0.023)\end{array}$ & $\begin{array}{l}0.0169 \\
(0.017)\end{array}$ \\
\hline Top 10 Banks & & $\begin{array}{l}0.7251 \\
(0.758)\end{array}$ & & & & $\begin{array}{l}0.0226^{* *} \\
(0.010)\end{array}$ & & \\
\hline Chinese lending & & & $\begin{array}{l}0.5055 \\
(0.521)\end{array}$ & & & & $\begin{array}{l}0.0104 \\
(0.010)\end{array}$ & \\
\hline OECD ODA & & & & $\begin{array}{l}-0.0970 \\
(0.289)\end{array}$ & & & & $\begin{array}{l}0.0027 \\
(0.005)\end{array}$ \\
\hline$\sum_{k=0}^{2} M D B_{-}$Support $_{\mathrm{cs}, \mathrm{t}-\mathrm{k}}$ & 0.570 & 0.463 & $2.397^{*}$ & 0.623 & 0.0421 & 0.0388 & 0.0858 & 0.0444 \\
\hline Wald test : $p$ value & 0.640 & 0.699 & 0.0900 & 0.570 & 0.281 & 0.308 & 0.171 & 0.356 \\
\hline Observations & 13,869 & 13,869 & 6,318 & 11,718 & 13,869 & 13,869 & 6,318 & 11,718 \\
\hline R-squared & 0.638 & 0.638 & 0.763 & 0.610 & 0.563 & 0.564 & 0.654 & 0.551 \\
\hline Sector-country FE & Yes & Yes & Yes & Yes & Yes & Yes & Yes & Yes \\
\hline Sector-year FE & Yes & Yes & Yes & Yes & Yes & Yes & Yes & Yes \\
\hline Country-year FE & Yes & Yes & Yes & Yes & Yes & Yes & Yes & Yes \\
\hline Average MDB & 0.0713 & 0.0713 & 0.0954 & 0.0621 & 0.0713 & 0.0713 & 0.0954 & 0.0621 \\
\hline Average Number of Bonds & 1.331 & 1.331 & 1.934 & 1.080 & & & & \\
\hline Average Bond Size (\%GDP) & & & & & 0.0396 & 0.0396 & 0.0538 & 0.0368 \\
\hline
\end{tabular}

Notes: The table presents estimates of equation 1 on corporate bonds. The dependent variables are number of bonds (columns 1-4), and size of bonds (\% of GDP) (columns 5-8) in the country-sector-year. $\mathrm{MDB}_{\mathrm{cs}, \mathrm{t}}$ is a dummy equal to 1 if there is at least one MDB providing a syndicated loan in country-sector $c s$ at time $t$. To control for the top 10 banks according to S\&P, we include a dummy equal to 1 if at least 1 of the top banks was present in the country-sector in the previous 2 years. To control for Chinese official financing and official development assistance (ODA), we include a dummy equal to 1 if the country-sector received them in the previous 2 years. The cumulative effect of $\mathrm{MDB}_{\mathrm{cs}, \mathrm{t}}$ between year $t-2$ and $t$, and the the $\mathrm{p}$-value of a Wald test showing its significance, are also reported. The last rows show the averages of $\mathrm{MDB}_{\mathrm{cs}, \mathrm{t}}$ and the outcome variables in the estimation. Standard errors clustered at country level are in parentheses: ${ }^{*} \mathrm{p}<0.1,{ }^{* *} \mathrm{p}<0.05,{ }^{* * *} \mathrm{p}<0.01$. 
Table 9: Inter-sectoral Spillover Effects

\begin{tabular}{|c|c|c|c|c|}
\hline & $\begin{array}{l}\text { Number } \\
\text { of loans } \\
(1)\end{array}$ & $\begin{array}{l}\text { Size (\% GDP) } \\
(2)\end{array}$ & $\begin{array}{l}\text { Banks } \\
\text { (3) }\end{array}$ & $\begin{array}{l}\text { Maturity } \\
\text { (4) }\end{array}$ \\
\hline $\mathrm{MDB}_{\mathrm{cs}, \mathrm{t}}$ & $\begin{array}{l}0.7293 \\
(0.614)\end{array}$ & $\begin{array}{l}0.0839^{* *} \\
(0.032)\end{array}$ & $\begin{array}{l}0.8992^{* * *} \\
(0.321)\end{array}$ & $\begin{array}{l}0.3585^{* * *} \\
(0.121)\end{array}$ \\
\hline $\mathrm{MDB}_{\mathrm{cs}, \mathrm{t}-1}$ & $\begin{array}{l}0.8225^{*} \\
(0.458)\end{array}$ & $\begin{array}{l}0.0287 \\
(0.025)\end{array}$ & $\begin{array}{l}0.7237^{* * *} \\
(0.212)\end{array}$ & $\begin{array}{l}0.1413 \\
(0.103)\end{array}$ \\
\hline $\mathrm{MDB}_{\mathrm{cs}, \mathrm{t}-2}$ & $\begin{array}{l}0.7850^{*} \\
(0.447)\end{array}$ & $\begin{array}{l}0.0556^{* * *} \\
(0.019)\end{array}$ & $\begin{array}{l}0.6731^{* *} \\
(0.267)\end{array}$ & $\begin{array}{l}0.2908^{* * * *} \\
(0.093)\end{array}$ \\
\hline MDB in other sector ${ }_{c \bar{c}, t}$ & $\begin{array}{l}-0.2700 \\
(1.023)\end{array}$ & $\begin{array}{l}0.0256 \\
(0.050)\end{array}$ & $\begin{array}{l}0.7779 * * \\
(0.341)\end{array}$ & $\begin{array}{l}0.0008 \\
(0.181)\end{array}$ \\
\hline $\begin{array}{l}\sum_{k=0}^{2} M D B_{\mathrm{cs}, \mathrm{t}-\mathrm{k}} \\
\text { Wald test : } p \text { value }\end{array}$ & $\begin{array}{l}2.337^{*} \\
0.0858\end{array}$ & $\begin{array}{l}0.168^{* * *} \\
0.00609\end{array}$ & $\begin{array}{l}2.296^{* * *} \\
0.00138\end{array}$ & $\begin{array}{l}0.791^{* * *} \\
1.62 \mathrm{e}-05\end{array}$ \\
\hline Observations & 24,219 & 24,219 & 24,219 & 24,023 \\
\hline R-squared & 0.607 & 0.381 & 0.659 & 0.522 \\
\hline Sector-country FE & Yes & Yes & Yes & Yes \\
\hline Sector-year FE & Yes & Yes & Yes & Yes \\
\hline Country-year FE & Yes & Yes & Yes & Yes \\
\hline Average MDB & 0.0483 & 0.0483 & 0.0483 & 0.0477 \\
\hline Average Number of Loans & 0.760 & & & \\
\hline Average Size (\%GDP) & & 0.105 & & \\
\hline Average Banks & & & 1.526 & \\
\hline Average Maturity & & & & 0.755 \\
\hline
\end{tabular}

Notes: The table presents estimates of equation 1, controlling for the presence of MDBs in another sector. The dependent variables are number of loans (column 1), size of syndicated loans (\% of GDP) (column 2), banks per loan (column 3), and maturity of syndicated loans (in years) (column 4) in the country-sector-year. $\mathrm{MDB}_{\mathrm{cs}, \mathrm{t}}$ is a dummy equal to 1 if there is at least one MDB providing a syndicated loan in country-sector $c s$ at time $t$. The cumulative effect of $M_{\text {DB, }}$ between year $t-2$ and $t$, and the the $\mathrm{p}$-value of a Wald test showing its significance, are also reported. MDB in other sector ${ }_{\mathrm{cs}, t}$ is a dummy equal to 1 if there is at least one MDB providing a syndicated loan in another sector $s$ of country $c$ at time $t$. The last rows show the averages of $\mathrm{MDB}_{\mathrm{cs}, \mathrm{t}}$ and the outcome variables in the estimation. Standard errors clustered at country level are in parentheses: ${ }^{*} \mathrm{p}<0.1,{ }^{* *} \mathrm{p}<0.05,{ }^{* * *} \mathrm{p}<0.01$. 
Table 10: Effects in Infrastructure

\begin{tabular}{|c|c|c|c|c|}
\hline & $\begin{array}{l}\text { Number } \\
\text { of loans } \\
(1)\end{array}$ & $\begin{array}{l}\text { Size (\% GDP) } \\
\text { (2) }\end{array}$ & $\begin{array}{l}\text { Banks } \\
\text { (3) }\end{array}$ & $\begin{array}{l}\text { Maturity } \\
\text { (4) }\end{array}$ \\
\hline $\mathrm{MDB}_{\mathrm{cs}, \mathrm{t}}$ & $\begin{array}{l}1.8310 \\
(1.799)\end{array}$ & $\begin{array}{l}0.0656 \\
(0.045)\end{array}$ & $\begin{array}{l}0.5588 \\
(0.563)\end{array}$ & $\begin{array}{l}0.8073^{* * *} \\
(0.230)\end{array}$ \\
\hline $\mathrm{MDB}_{\mathrm{cs}, \mathrm{t}-1}$ & $\begin{array}{l}1.9705 \\
(1.621)\end{array}$ & $\begin{array}{l}0.0107 \\
(0.052)\end{array}$ & $\begin{array}{l}0.9577^{* *} \\
(0.441)\end{array}$ & $\begin{array}{l}0.8271^{* * *} \\
(0.255)\end{array}$ \\
\hline $\mathrm{MDB}_{\mathrm{cs}, \mathrm{t}-2}$ & $\begin{array}{l}2.3603 \\
(1.745)\end{array}$ & $\begin{array}{l}-0.0098 \\
(0.049)\end{array}$ & $\begin{array}{l}0.6816^{*} \\
(0.408)\end{array}$ & $\begin{array}{l}0.9708^{* * *} \\
(0.234)\end{array}$ \\
\hline$\sum_{k=0}^{2} M D B_{\mathrm{cs}, \mathrm{t}-\mathrm{k}}$ & 6.162 & 0.0665 & $2.198^{*}$ & $2.605^{* * *}$ \\
\hline Wald test : $p$ value & 0.232 & 0.522 & 0.0571 & $1.27 \mathrm{e}-07$ \\
\hline Observations & 2,691 & 2,691 & 2,691 & 2,642 \\
\hline R-squared & 0.456 & 0.264 & 0.478 & 0.434 \\
\hline Sector-country FE & Yes & Yes & Yes & Yes \\
\hline Sector-year FE & Yes & Yes & Yes & Yes \\
\hline Country-year FE & Yes & Yes & Yes & Yes \\
\hline Average MDB & 0.123 & 0.123 & 0.123 & 0.122 \\
\hline Average Number of Loans & 1.865 & & & \\
\hline Average Size (\%GDP) & & 0.363 & & \\
\hline Average Banks & & & 2.919 & \\
\hline Average Maturity & & & & 2.150 \\
\hline
\end{tabular}

Notes: The table presents estimates of equation 1 in the infrastructure sector only. The dependent variables are number of loans (column 1), size of syndicated loans (\% of GDP) (column 2), banks per loan (column 3), and maturity of syndicated loans (in years) (column 4) in the country-sector-year. $\mathrm{MDB}_{\mathrm{cs}, \mathrm{t}}$ is a dummy equal to 1 if there is at least one MDB providing a syndicated loan in country-sector $c s$ at time $t$. The last rows show the averages of $\mathrm{MDB}_{\mathrm{cs}, \mathrm{t}}$ and the outcome variables in the estimation. Standard errors clustered at country level are in parentheses: ${ }^{*} p<0.1,{ }^{* *} p<0.05,{ }^{* * *} p<0.01$. 
Table 11: Effects in Countries by Investment Grade Rating

\begin{tabular}{|c|c|c|c|c|c|c|c|c|}
\hline & \multicolumn{4}{|c|}{ W/o Investment Grade Rating } & \multicolumn{4}{|c|}{ With Investment Grade Rating } \\
\hline & $\begin{array}{l}\text { Number } \\
\text { of Loans } \\
\text { (1) }\end{array}$ & $\begin{array}{l}\text { Size } \\
(\% G D P) \\
(2)\end{array}$ & $\begin{array}{l}\text { Banks } \\
\text { (3) }\end{array}$ & $\begin{array}{l}\text { Maturity } \\
(4)\end{array}$ & $\begin{array}{l}\text { Number } \\
\text { of Loans } \\
\text { (5) }\end{array}$ & $\begin{array}{l}\text { Size } \\
(\% G D P) \\
(6)\end{array}$ & $\begin{array}{l}\text { Banks } \\
\text { (7) }\end{array}$ & $\begin{array}{l}\text { Maturity } \\
\text { (8) }\end{array}$ \\
\hline $\mathrm{MDB}_{\mathrm{cs}, \mathrm{t}}$ & $\begin{array}{l}0.0581 \\
(0.425)\end{array}$ & $\begin{array}{l}0.0263 \\
(0.020)\end{array}$ & $\begin{array}{l}0.6261^{* * *} \\
(0.236)\end{array}$ & $\begin{array}{l}0.3973^{* * *} \\
(0.122)\end{array}$ & $\begin{array}{l}1.4874^{* *} \\
(0.721)\end{array}$ & $\begin{array}{l}0.1443 \\
(0.089)\end{array}$ & $\begin{array}{l}-0.3733 \\
(0.505)\end{array}$ & $\begin{array}{l}0.1733 \\
(0.209)\end{array}$ \\
\hline $\mathrm{MDB}_{\mathrm{cs}, \mathrm{t}-1}$ & $\begin{array}{l}0.0577 \\
(0.401)\end{array}$ & $\begin{array}{l}-0.0193 \\
(0.019)\end{array}$ & $\begin{array}{l}0.4072^{*} \\
(0.235)\end{array}$ & $\begin{array}{l}0.1187 \\
(0.118)\end{array}$ & $\begin{array}{l}1.4380^{* *} \\
(0.557)\end{array}$ & $\begin{array}{l}0.1151 \\
(0.073)\end{array}$ & $\begin{array}{l}1.1100^{*} \\
(0.573)\end{array}$ & $\begin{array}{l}0.2107 \\
(0.190)\end{array}$ \\
\hline $\mathrm{MDB}_{\mathrm{cs}, \mathrm{t}-2}$ & $\begin{array}{l}0.2631 \\
(0.282)\end{array}$ & $\begin{array}{l}0.0442^{* *} \\
(0.020)\end{array}$ & $\begin{array}{l}0.5769^{*} \\
(0.310)\end{array}$ & $\begin{array}{l}0.3268^{* * *} \\
(0.111)\end{array}$ & $\begin{array}{l}0.7320 \\
(0.440)\end{array}$ & $\begin{array}{l}0.0639 \\
(0.052)\end{array}$ & $\begin{array}{l}0.6812 \\
(0.542)\end{array}$ & $\begin{array}{l}0.2077 \\
(0.172)\end{array}$ \\
\hline$\sum_{k=0}^{2} M D B_{-} S_{u p p o r t} t_{\mathrm{cs}, \mathrm{t}-\mathrm{k}}$ & 0.379 & 0.0511 & $1.610^{* *}$ & $0.843^{* * *}$ & $3.657^{* *}$ & $0.323^{*}$ & 1.418 & $0.592^{* *}$ \\
\hline Wald test : $p$ value & 0.725 & 0.132 & 0.0130 & 0.000137 & 0.0305 & 0.0957 & 0.299 & 0.0673 \\
\hline Observations & 19,881 & 19,881 & 19,881 & 19,745 & 4,284 & 4,284 & 4,284 & 4,225 \\
\hline R-squared & 0.526 & 0.370 & 0.698 & 0.462 & 0.810 & 0.468 & 0.658 & 0.580 \\
\hline Sector-country FE & Yes & Yes & Yes & Yes & Yes & Yes & Yes & Yes \\
\hline Sector-year FE & Yes & Yes & Yes & Yes & Yes & Yes & Yes & Yes \\
\hline Country-year FE & Yes & Yes & Yes & Yes & Yes & Yes & Yes & Yes \\
\hline Average MDB & 0.0416 & 0.0416 & 0.0416 & 0.0410 & 0.0796 & 0.0796 & 0.0796 & 0.0800 \\
\hline Average Number of Loans & 0.404 & & & & 2.417 & & & \\
\hline Average Size (\%GDP) & & 0.0740 & & & & 0.250 & & \\
\hline Average Banks & & & 0.902 & & & & 4.424 & \\
\hline Average Maturity & & & & 0.474 & & & & 2.068 \\
\hline
\end{tabular}

Notes: The table presents estimates of equation 1 by investment grade rating: the sample in columns 1-4 is restricted to countries in years when they do not retain investment grade rating; the sample in columns 5-6 is restricted to countries in years with investment grade rating. The dependent variables are number of loans, size of syndicated loans (\% of GDP), number of banks, and maturity of syndicated loans (in years) in the country-sector-year. MDB $_{\mathrm{cs}, \mathrm{t}}$ is a dummy equal to 1 if there is at least one MDB providing a syndicated loan in country-sector $c s$ at time $t$. The cumulative effect of $\mathrm{MDB}_{\mathrm{cs}, t}$ between year $t-2$ and $t$, and the the $\mathrm{p}$-value of a Wald test showing its significance, are also reported. The last rows show the averages of $\mathrm{MDB}_{\mathrm{cs}, t}$ and the outcome variables in the estimation. Standard errors clustered at country level are in parentheses: ${ }^{*} \mathrm{p}<0.1,{ }^{* *} \mathrm{p}<0.05,{ }^{* * *} \mathrm{p}<0.01$. 
Table 12: Effects by Financial Development

\begin{tabular}{|c|c|c|c|c|c|c|c|c|}
\hline & \multicolumn{4}{|c|}{ More Financially Developed } & \multicolumn{4}{|c|}{ Less Financially Developed } \\
\hline & $\begin{array}{l}\text { Number } \\
\text { of Loans } \\
(1)\end{array}$ & $\begin{array}{l}\text { Size } \\
(\% G D P) \\
(2)\end{array}$ & $\begin{array}{l}\text { Banks } \\
\text { (3) }\end{array}$ & $\begin{array}{l}\text { Maturity } \\
\text { (4) }\end{array}$ & $\begin{array}{l}\text { Number } \\
\text { of Loans } \\
(5)\end{array}$ & $\begin{array}{l}\text { Size } \\
(\% G D P) \\
(6)\end{array}$ & $\begin{array}{l}\text { Banks } \\
\text { (7) }\end{array}$ & $\begin{array}{l}\text { Maturity } \\
(8)\end{array}$ \\
\hline $\mathrm{MDB}_{\mathrm{cs}, \mathrm{t}}$ & $\begin{array}{l}1.2022 \\
(0.870)\end{array}$ & $\begin{array}{l}0.1005^{* * *} \\
(0.033)\end{array}$ & $\begin{array}{l}0.5860^{*} \\
(0.309)\end{array}$ & $\begin{array}{l}0.3489^{* * * *} \\
(0.098)\end{array}$ & $\begin{array}{l}0.3246 \\
(0.238)\end{array}$ & $\begin{array}{l}0.0313 \\
(0.024)\end{array}$ & $\begin{array}{l}0.4716 \\
(0.287)\end{array}$ & $\begin{array}{l}0.3901^{* *} \\
(0.180)\end{array}$ \\
\hline $\mathrm{MDB}_{\mathrm{cs}, \mathrm{t}-1}$ & $\begin{array}{l}1.1873 \\
(0.735)\end{array}$ & $\begin{array}{l}0.0597 \\
(0.038)\end{array}$ & $\begin{array}{l}0.9150^{* * *} \\
(0.310)\end{array}$ & $\begin{array}{l}0.0743 \\
(0.131)\end{array}$ & $\begin{array}{l}0.2237 \\
(0.188)\end{array}$ & $\begin{array}{l}-0.0087 \\
(0.020)\end{array}$ & $\begin{array}{l}0.4521^{*} \\
(0.246)\end{array}$ & $\begin{array}{l}0.2662 \\
(0.161)\end{array}$ \\
\hline $\mathrm{MDB}_{\mathrm{cs}, \mathrm{t}-2}$ & $\begin{array}{l}1.0907 \\
(0.681)\end{array}$ & $\begin{array}{l}0.0639^{* * *} \\
(0.023)\end{array}$ & $\begin{array}{l}0.7402^{* *} \\
(0.350)\end{array}$ & $\begin{array}{l}0.2492^{* *} \\
(0.106)\end{array}$ & $\begin{array}{l}0.2668 \\
(0.213)\end{array}$ & $\begin{array}{l}0.0460 \\
(0.030)\end{array}$ & $\begin{array}{l}0.5626 \\
(0.444)\end{array}$ & $\begin{array}{l}0.3369^{*} \\
(0.170)\end{array}$ \\
\hline$\sum_{k=0}^{2} M D B_{-}$Support $t_{\mathrm{cs}, \mathrm{t}-\mathrm{k}}$ & 3.480 & $0.224^{* * *}$ & $2.241^{* * *}$ & $0.672^{* * *}$ & 0.815 & 0.0687 & 1.486 & $0.993^{* * *}$ \\
\hline Wald test : $p$ value & 0.127 & 0.00460 & 0.00764 & 0.000250 & 0.192 & 0.141 & 0.101 & 0.00223 \\
\hline Observations & 11,799 & 11,799 & 11,799 & 11,685 & 11,799 & 11,799 & 11,799 & 11,721 \\
\hline R-squared & 0.638 & 0.440 & 0.668 & 0.547 & 0.397 & 0.323 & 0.582 & 0.439 \\
\hline Sector-country FE & Yes & Yes & Yes & Yes & Yes & Yes & Yes & Yes \\
\hline Sector-year FE & Yes & Yes & Yes & Yes & Yes & Yes & Yes & Yes \\
\hline Country-year FE & Yes & Yes & Yes & Yes & Yes & Yes & Yes & Yes \\
\hline Average MDB & 0.0614 & 0.0614 & 0.0614 & 0.0611 & 0.0364 & 0.0364 & 0.0364 & 0.0357 \\
\hline Average Number of Loans & 1.282 & & & & 0.272 & & & \\
\hline Average Size (\%GDP) & & 0.139 & & & & 0.0610 & & \\
\hline Average Banks & & & 2.510 & & & & 0.611 & \\
\hline Average Maturity & & & & 1.132 & & & & 0.402 \\
\hline
\end{tabular}

Notes: The table presents estimates of equation 1 by financial development: the sample in columns 1-4 is restricted to more financially developed countries; the sample in columns 5-6 is restricted to less financially developed countries. Countries are considered more (less) financially developed if their average domestic credit to the private sector by banks (\% of GDP) is above (below) the median. Domestic private sector by banks (\% of GDP) comes from the World Bank's World Development Indicators. Countries by financial development are listed in Table A2. The dependent variables are number of loans, size of syndicated loans (\% of

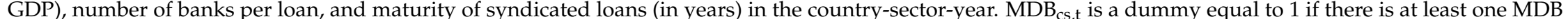
providing a syndicated loan in country-sector $c s$ at time $t$. The cumulative effect of $\mathrm{MDB}_{\mathrm{cs}, \mathrm{t}}$ between year $t-2$ and $t$, and the the p-value of a Wald test showing its significance, are also reported. The last rows show the averages of $\mathrm{MDB}_{\mathrm{cs}, \mathrm{t}}$ and the outcome variables in the estimation. Standard errors clustered at country level are in parentheses: ${ }^{*} \mathrm{p}<0.1,{ }^{* *} \mathrm{p}<0.05,{ }^{* * *} \mathrm{p}<0.01$ 
Table 13: Effects in Low Income Countries and Low Growth Country-years

\begin{tabular}{|c|c|c|c|c|c|c|c|c|}
\hline & \multicolumn{4}{|c|}{ Low Income Countries } & \multicolumn{4}{|c|}{ Low Growth Country-years } \\
\hline & $\begin{array}{l}\text { Number } \\
\text { of Loans } \\
(1)\end{array}$ & $\begin{array}{l}\text { Size } \\
(\% G D P) \\
(2)\end{array}$ & $\begin{array}{l}\text { Banks } \\
(3)\end{array}$ & $\begin{array}{l}\text { Maturity } \\
(4)\end{array}$ & $\begin{array}{l}\text { Number } \\
\text { of Loans } \\
(5)\end{array}$ & $\begin{array}{l}\text { Size } \\
(\% G D P) \\
(6)\end{array}$ & $\begin{array}{l}\text { Banks } \\
(7)\end{array}$ & $\begin{array}{l}\text { Maturity } \\
(8)\end{array}$ \\
\hline $\mathrm{MDB}_{\mathrm{cs}, \mathrm{t}}$ & $\begin{array}{l}0.0197 \\
(0.035)\end{array}$ & $\begin{array}{l}-0.0441 \\
(0.041)\end{array}$ & $\begin{array}{l}0.0342 \\
(0.174)\end{array}$ & $\begin{array}{l}0.1992 \\
(0.236)\end{array}$ & $\begin{array}{l}-0.0496 \\
(0.618)\end{array}$ & $\begin{array}{l}0.0689^{* *} \\
(0.027)\end{array}$ & $\begin{array}{l}0.2075 \\
(0.277)\end{array}$ & $\begin{array}{l}0.2902^{* *} \\
(0.137)\end{array}$ \\
\hline $\mathrm{MDB}_{\mathrm{cs}, \mathrm{t}-1}$ & $\begin{array}{l}-0.0125 \\
(0.037)\end{array}$ & $\begin{array}{l}-0.0428 \\
(0.035)\end{array}$ & $\begin{array}{l}-0.1729 \\
(0.160)\end{array}$ & $\begin{array}{l}-0.0274 \\
(0.165)\end{array}$ & $\begin{array}{l}0.0271 \\
(0.484)\end{array}$ & $\begin{array}{l}0.0055 \\
(0.023)\end{array}$ & $\begin{array}{l}0.3667 \\
(0.246)\end{array}$ & $\begin{array}{l}0.3588^{* *} \\
(0.154)\end{array}$ \\
\hline $\mathrm{MDB}_{\mathrm{cs}, \mathrm{t}-2}$ & $\begin{array}{l}0.1369^{* *} \\
(0.061)\end{array}$ & $\begin{array}{l}0.0384 \\
(0.045)\end{array}$ & $\begin{array}{l}0.5424^{* *} \\
(0.262)\end{array}$ & $\begin{array}{l}0.6037^{*} \\
(0.333)\end{array}$ & $\begin{array}{l}-0.0989 \\
(0.360)\end{array}$ & $\begin{array}{l}0.0529^{*} \\
(0.027)\end{array}$ & $\begin{array}{l}0.1005 \\
(0.368)\end{array}$ & $\begin{array}{l}0.2805^{* *} \\
(0.138)\end{array}$ \\
\hline$\sum_{k=0}^{2} M D B_{-} S_{\text {Support }} \mathrm{cs}, \mathrm{t}-\mathrm{k}$ & 0.144 & -0.0484 & 0.404 & 0.775 & -0.121 & $0.127^{* * *}$ & 0.675 & $0.930^{* * *}$ \\
\hline Wald test : $p$ value & 0.187 & 0.426 & 0.258 & 0.235 & 0.933 & 0.00288 & 0.343 & 0.000115 \\
\hline Observations & 5,175 & 5,175 & 5,175 & 5,159 & 11,709 & 11,709 & 11,709 & 11,604 \\
\hline R-squared & 0.437 & 0.436 & 0.336 & 0.377 & 0.536 & 0.455 & 0.617 & 0.525 \\
\hline Sector-country FE & Yes & Yes & Yes & Yes & Yes & Yes & Yes & Yes \\
\hline Sector-year FE & Yes & Yes & Yes & Yes & Yes & Yes & Yes & Yes \\
\hline Country-year FE & Yes & Yes & Yes & Yes & Yes & Yes & Yes & Yes \\
\hline Average MDB & 0.0139 & 0.0139 & 0.0139 & 0.0140 & 0.0449 & 0.0449 & 0.0449 & 0.0448 \\
\hline Average Number of Loans & 0.0356 & & & & 0.627 & & & \\
\hline Average Size (\%GDP) & & 0.0526 & & & & 0.0996 & & \\
\hline Average Banks & & & 0.122 & & & & 1.343 & \\
\hline Average Maturity & & & & 0.110 & & & & 0.718 \\
\hline
\end{tabular}

Notes: The table presents estimates of equation 1 in different sub-samples. The sample in columns 1-4 is limited to low income countries (listed in Table A3). The income level of the country is based on country classification for the World Bank's 2018 fiscal year. The threshold for low-income countries is GNI per capita smaller than 995 current USD. The sample in columns 5-8 is limited to country-years in which constant GDP growth is below the sample median. GDP growth is taken from the IMF's World Economic Outlook. The dependent variables are number of loans, size of syndicated loans (\% of GDP), number of banks per loan, and maturity of syndicated loans (in years) in the country-sector-year. $\mathrm{MDB}_{\mathrm{cs}, \mathrm{t}}$ is a dummy equal to 1 if there is at least one MDB providing a syndicated loan in country-sector $c s$ at time $t$. The cumulative effect of $\mathrm{MDB}_{\mathrm{cs}, t}$ between year $t-2$ and $t$, and the the p-value of a Wald test showing its significance, are also reported. The last rows show the averages of $\mathrm{MDB}_{\mathrm{cs}, \mathrm{t}}$ and the outcome variables in the estimation. Standard errors clustered at country level are in parentheses: ${ }^{*} \mathrm{p}<0.1,{ }^{* *} \mathrm{p}<0.05,{ }^{* * *} \mathrm{p}<0.01$. 


\section{Online Appendix-Not for publication}

Table A1: Amounts lent in 1993-2017 by Multilateral Organizations

\begin{tabular}{|c|c|}
\hline Multilateral Development Bank & USD (million) \\
\hline European Investment Bank - EIB & 45,528 \\
\hline European Bank for Reconstruction and Development - EBRD & 45,064 \\
\hline International Finance Corporation - IFC & 41,062 \\
\hline International Bank for Reconstruction \& Development - World Bank & 35,228 \\
\hline Inter-American Development Bank - IADB & 24,611 \\
\hline African Development Bank & 13,070 \\
\hline Asian Development Bank & 8,293 \\
\hline Islamic Development Bank & 7,274 \\
\hline Corporacion Andina de Fomento - CAF Development Bank of Latin America & 4,115 \\
\hline Eurasian Development Bank & 3,989 \\
\hline Nordic Investment Bank & 2,888 \\
\hline African Export-Import Bank - Afreximbank & 2,783 \\
\hline InternationalIslamic Trade Finance Corp - ITFC & 1.169 \\
\hline Clean Technology Fund & 769 \\
\hline International Investment Bank - IIB & 709 \\
\hline International Development Association - IDA & 645 \\
\hline AfricaFinance Corp - AFC & 554 \\
\hline Inter-AmericanInvestment Corp (IIC) & 533 \\
\hline Asian Infrastructure Investment Bank & 462 \\
\hline CABEI & 422 \\
\hline Banco del Desarrollo & 377 \\
\hline Andean Development Corp & 350 \\
\hline East African Development Bank & 181 \\
\hline Islamic Corp for the Development of the Private Sector - ICD & 169 \\
\hline West African Development Bank - BOAD & 115 \\
\hline Multilateral Investment Guarantee Agency & 112 \\
\hline Caribbean Development Bank - CDB & 107 \\
\hline Banque de Developpement des Etats de I'Afrique Centrale - BDEAC & 60 \\
\hline Corporacao Inter-Americana de Investimento & 14 \\
\hline Islamic Corp for Insurance of Investments \& Export Credits - ICIEC & 10 \\
\hline Nordic Development Fund & 8 \\
\hline Eurasian Bank & 4 \\
\hline
\end{tabular}

Notes: The table lists the MDBs providing syndicate loans to developing countries in 1993-2017, and the amount they lent (USD million) across the period. 
Table A2: Countries by Financial Development

\section{High Financial Development Countries}

Antigua and Barbuda, The Bahamas, Bahrain, Bangladesh, Belize, Bolivia, Bosnia and Herzegovina, Brazil, Bulgaria, Cabo Verde, Colombia, Costa Rica, Croatia, Djibouti, Egypt, El Salvador, Grenada, Guyana, Honduras, Hungary, India, Indonesia, Jordan, Kazakhstan, Kuwait, Lebanon, Macedonia, FYR, Malaysia, Maldives, Mauritius, Mongolia, Montenegro, Rep. of, Morocco, Namibia, Nepal, Oman, Panama, Paraguay, Philippines, Poland, Qatar, Russia, Saudi Arabia, Serbia, South Africa, Sri Lanka, St. Lucia, Thailand, Trinidad and Tobago, Tunisia, Turkey, Ukraine, United Arab Emirates, Uruguay, Vanuatu, Vietnam and Zimbabwe

\section{Low Financial Development Countries}

Afghanistan, Albania, Algeria, Angola, Argentina, Armenia, Azerbaijan, Belarus, Benin, Burkina Faso, Cambodia, Chad, Dominican Republic, Ecuador, Equatorial Guinea, Eritrea, Ethiopia, Gabon, Georgia, Ghana, Guatemala, Guinea, Haiti, Iraq, Jamaica, Kenya, Kyrgyz Republic, Lao P.D.R., Liberia, Libya, Madagascar, Malawi, Mali, Mauritania, Mexico, Moldova, Mozambique, Myanmar, Nicaragua, Niger, Nigeria, Pakistan, Papua New Guinea, Peru, Romania, Rwanda, Senegal, Sierra Leone, Sudan, Syria, Tajikistan, Tanzania, Togo, Uganda, Venezuela, Yemen and Zambia

Notes: The financial development of the country is based on average domestic credit to the private sector by banks (\% of GDP) below or above the median in the sample. Domestic private sector by banks (\% of GDP) comes from the World Bank's World Development Indicators.

Table A3: Countries by Income Levels

\section{Low Income Countries}

Afghanistan, Benin, Burkina Faso, Chad, Eritrea, Ethiopia, Guinea, Haiti, Liberia, Madagascar, Malawi, Mali, Mozambique, Nepal, Niger, Rwanda, Senegal, Sierra Leone, Syria, Tajikistan, Tanzania, Togo, Uganda, Yemen,

Zimbabwe

Middle and High Income Countries

Albania, Algeria, Angola, Antigua and Barbuda, Argentina, Armenia, Azerbaijan, Bahamas, Bahrain, Bangladesh, Belarus, Belize, Bolivia, Bosnia and Herzegovina, Brazil, Bulgaria, Cambodia, Cape Verde, Colombia, Costa Rica, Croatia, Djibouti, Dominican Republic, Ecuador, Egypt, El Salvador, Equatorial Guinea, Gabon, Georgia, Ghana, Grenada, Guatemala, Guyana, Honduras, Hungary, India, Indonesia, Iraq, Jamaica, Jordan, Kazakhstan, Kenya, Kuwait, Kyrgyzstan, Laos, Lebanon, Libya, Macedonia, Malaysia, Maldives, Marshall Islands, Mauritania, Mauritius, Mexico, Moldova, Mongolia, Montenegro, Morocco, Myanmar, Namibia, Nicaragua, Nigeria, Oman, Pakistan, Panama, Papua New Guinea, Paraguay, Peru, Philippines, Poland, Qatar, Romania, Russian Federation, Saint Lucia, Saudi Arabia, Serbia, South Africa, Sri Lanka, Sudan, Thailand, Trinidad and Tobago, Tunisia, Turkey, Turkmenistan, Ukraine, United Arab Emirates, Uruguay, Uzbekistan, Vanuatu, Venezuela, Vietnam, Zambia

Notes: The income level of the country is based on country classification for the World Bank's 2018 fiscal year. The threshold for low-income countries is GNI per capita smaller than 995 current USD. 
Table A4: Robustness: No Outliers by Country

\begin{tabular}{|c|c|c|c|c|}
\hline & $\begin{array}{l}\text { Number } \\
\text { of loans } \\
(1)\end{array}$ & $\begin{array}{l}\text { Size (\% GDP) } \\
\text { (2) }\end{array}$ & $\begin{array}{l}\text { Banks } \\
\text { (3) }\end{array}$ & $\begin{array}{l}\text { Maturity } \\
\text { (4) }\end{array}$ \\
\hline $\mathrm{MDB}_{\mathrm{cs}, \mathrm{t}}$ & $\begin{array}{l}1.2852 \\
(0.843)\end{array}$ & $\begin{array}{l}0.0930^{* * *} \\
(0.031)\end{array}$ & $\begin{array}{l}0.7110^{* *} \\
(0.346)\end{array}$ & $\begin{array}{l}0.2802^{* *} \\
(0.116)\end{array}$ \\
\hline $\mathrm{MDB}_{\mathrm{cs}, \mathrm{t}-1}$ & $\begin{array}{l}1.2331^{*} \\
(0.713)\end{array}$ & $\begin{array}{l}0.0650^{*} \\
(0.036)\end{array}$ & $\begin{array}{l}1.0474^{* * *} \\
(0.325)\end{array}$ & $\begin{array}{l}0.1772 \\
(0.146)\end{array}$ \\
\hline $\mathrm{MDB}_{\mathrm{cs}, \mathrm{t}-2}$ & $\begin{array}{l}1.1378^{*} \\
(0.659)\end{array}$ & $\begin{array}{l}0.0781^{* * *} \\
(0.024)\end{array}$ & $\begin{array}{l}0.9695^{* *} \\
(0.412)\end{array}$ & $\begin{array}{l}0.2685^{* *} \\
(0.107)\end{array}$ \\
\hline $\begin{array}{l}\sum_{k=0}^{2} M D B_{\mathrm{cs}, \mathrm{t}-\mathrm{k}} \\
\text { Wald test : } p \text { value }\end{array}$ & 3.656 & $0.236^{* * *}$ & $2.728^{* * *}$ & $0.726^{* * *}$ \\
\hline Observations & 6,624 & 6,624 & 6,624 & 6,525 \\
\hline R-squared & 0.605 & 0.506 & 0.646 & 0.533 \\
\hline Sector-country FE & Yes & Yes & Yes & Yes \\
\hline Sector-year FE & Yes & Yes & Yes & Yes \\
\hline Country-year FE & Yes & Yes & Yes & Yes \\
\hline Average MDB & 0.116 & 0.116 & 0.116 & 0.116 \\
\hline Average Number of Loans & 2.593 & & & \\
\hline Average Size (\% GDP) & & 0.206 & & \\
\hline Average Banks & & & 4.919 & \\
\hline Average Maturity & & & & 2.117 \\
\hline
\end{tabular}

Notes: The table presents estimates of equation 1 in countries with more than 100 syndicated loans in 1993-2017: Qatar, Bahrain, Kuwait, Bulgaria, Croatia, Egypt, Vietnam, Panama, Pakistan, Nigeria, Saudi Arabia, Hungary, Romania, Colombia, Peru, Kazakhstan, Ukraine, Venezuela, South Africa, Poland, United Arab Emirates, Philippines, Malaysia, Argentina, Thailand, Mexico, Turkey, India, Indonesia, Russian Federation and Brazil. The dependent variables are number of loans (column 1), size of syndicated loans (\% of GDP) (column 2), banks per loan (column 3), and maturity of syndicated loans (in years) (column 4) in the country-sector-year. $\mathrm{MDB}_{\mathrm{cs}, \mathrm{t}}$ is a dummy equal to 1 if there is at least one MDB providing a syndicated loan in country-sector $c s$ at time $t$. The cumulative effect of $\mathrm{MDB}_{\mathrm{cs}, \mathrm{t}}$ between year $t-2$ and $t$, and the the p-value of a Wald test showing its significance, are also reported. The last rows show the averages of $\mathrm{MDB}_{\mathrm{cs}, \mathrm{t}}$ and the outcome variables in the estimation. Standard errors clustered at country-sector level in parentheses: * $\mathrm{p}<0.1,{ }^{* *} \mathrm{p}<0.05,{ }^{* * *} \mathrm{p}<0.01$. 
Table A5: Robustness: No Outliers by Sector

\begin{tabular}{|c|c|c|c|c|}
\hline & $\begin{array}{l}\text { Number } \\
\text { of loans } \\
(1)\end{array}$ & $\begin{array}{l}\text { Size (\% GDP) } \\
(2)\end{array}$ & $\begin{array}{l}\text { Banks } \\
\text { (3) }\end{array}$ & $\begin{array}{l}\text { Maturity } \\
\text { (4) }\end{array}$ \\
\hline $\mathrm{MDB}_{\mathrm{cs}, \mathrm{t}}$ & $\begin{array}{l}0.6636 \\
(0.629)\end{array}$ & $\begin{array}{l}0.0687^{* * *} \\
(0.025)\end{array}$ & $\begin{array}{l}0.2818 \\
(0.252)\end{array}$ & $\begin{array}{l}0.3842^{* * *} \\
(0.112)\end{array}$ \\
\hline $\mathrm{MDB}_{\mathrm{cs}, \mathrm{t}-1}$ & $\begin{array}{l}0.6164 \\
(0.521)\end{array}$ & $\begin{array}{l}0.0244 \\
(0.031)\end{array}$ & $\begin{array}{l}0.5547^{* *} \\
(0.230)\end{array}$ & $\begin{array}{l}0.0408 \\
(0.120)\end{array}$ \\
\hline $\mathrm{MDB}_{\mathrm{cs}, \mathrm{t}-2}$ & $\begin{array}{l}0.5958 \\
(0.441)\end{array}$ & $\begin{array}{l}0.0595^{* * *} \\
(0.021)\end{array}$ & $\begin{array}{l}0.5775^{* *} \\
(0.269)\end{array}$ & $\begin{array}{l}0.2836^{* * *} \\
(0.108)\end{array}$ \\
\hline $\begin{array}{l}\sum_{k=0}^{2} M D B_{\mathrm{cs}, \mathrm{t}-\mathrm{k}} \\
\text { Wald test : } p \text { value }\end{array}$ & 1.876 & $0.153^{* * *}$ & $1.414^{* *}$ & $0.709^{* * *}$ \\
\hline Observations & 13,455 & 13,455 & 13,455 & 13,303 \\
\hline R-squared & 0.682 & 0.450 & 0.710 & 0.567 \\
\hline Sector-country FE & Yes & Yes & Yes & Yes \\
\hline Sector-year FE & Yes & Yes & Yes & Yes \\
\hline Country-year FE & Yes & Yes & Yes & Yes \\
\hline Average MDB & 0.116 & 0.116 & 0.116 & 0.116 \\
\hline Average Number of Loans & 1.228 & & & \\
\hline Average Size (\% GDP) & & 0.164 & & \\
\hline Average Banks & & & 2.357 & \\
\hline Average Maturity & & & & 4.585 \\
\hline
\end{tabular}

Notes: The table presents estimates of equation 1 in sectors with more than 1,000 syndicated loans in 1993-2017: oil and gas, construction and real estate, manufacturing, infrastructure, and finance. The dependent variables are number of loans (column 1), size of syndicated loans (\% of GDP) (column 2), banks per loan (column 3), and maturity of syndicated loans (in years) (column 4 ) in the country-sector-year. $\mathrm{MDB}_{\mathrm{cs}, \mathrm{t}}$ is a dummy equal to 1 if there is at least one MDB providing a syndicated loan in country-sector $c s$ at time $t$. The cumulative effect of $\mathrm{MDB}_{\mathrm{cs}, \mathrm{t}}$ between year $t-2$ and $t$, and the the p-value of a Wald test showing its significance, are also reported. Standard errors clustered at country-sector level in parentheses: ${ }^{*} \mathrm{p}<0.1,{ }^{* *} \mathrm{p}<0.05,{ }^{* * *} \mathrm{p}<0.01$. 
Table A6: Robustness: No Outliers by Sector nor Country

\begin{tabular}{|c|c|c|c|c|}
\hline & $\begin{array}{l}\text { Number } \\
\text { of loans } \\
(1)\end{array}$ & $\begin{array}{l}\text { Size (\% GDP) } \\
\text { (2) }\end{array}$ & $\begin{array}{l}\text { Banks } \\
\text { (3) }\end{array}$ & $\begin{array}{l}\text { Maturity } \\
\text { (4) }\end{array}$ \\
\hline $\mathrm{MDB}_{\mathrm{cs}, \mathrm{t}}$ & $\begin{array}{l}0.9468 \\
(1.008)\end{array}$ & $\begin{array}{l}0.0823^{* *} \\
(0.036)\end{array}$ & $\begin{array}{l}0.2830 \\
(0.432)\end{array}$ & $\begin{array}{l}0.2884^{*} \\
(0.151)\end{array}$ \\
\hline $\mathrm{MDB}_{\mathrm{cs}, \mathrm{t}-1}$ & $\begin{array}{l}0.9102 \\
(0.852)\end{array}$ & $\begin{array}{l}0.0627 \\
(0.045)\end{array}$ & $\begin{array}{l}0.7569^{*} \\
(0.373)\end{array}$ & $\begin{array}{l}0.0760 \\
(0.161)\end{array}$ \\
\hline $\mathrm{MDB}_{\mathrm{cs}, \mathrm{t}-2}$ & $\begin{array}{l}0.8993 \\
(0.686)\end{array}$ & $\begin{array}{l}0.0874^{* * *} \\
(0.025)\end{array}$ & $\begin{array}{l}0.9045^{* *} \\
(0.423)\end{array}$ & $\begin{array}{l}0.2889^{* *} \\
(0.112)\end{array}$ \\
\hline $\begin{array}{l}\sum_{k=0}^{2} M D B_{\mathrm{cs}, \mathrm{t}-\mathrm{k}} \\
\text { Wald test : } p \text { value }\end{array}$ & 2.756 & $0.232^{* *}$ & $1.944^{*}$ & $0.653^{* * *}$ \\
\hline Observations & 3,680 & 3,680 & 3,680 & 3,611 \\
\hline R-squared & 0.670 & 0.537 & 0.661 & 0.519 \\
\hline Sector-country FE & Yes & Yes & Yes & Yes \\
\hline Sector-year FE & Yes & Yes & Yes & Yes \\
\hline Country-year FE & Yes & Yes & Yes & Yes \\
\hline Average MDB & 0.183 & 0.183 & 0.183 & 0.184 \\
\hline Average Number of Loans & 4.204 & & & \\
\hline Average Size (\%GDP) & & 0.341 & & \\
\hline Average Banks & & & 7.631 & \\
\hline Average Maturity & & & & 3.137 \\
\hline
\end{tabular}

Notes: The table presents estimates of equation 1 in sectors with more than 1,000 syndicated loans in 1993-2017 (oil and gas, construction and real estate, manufacturing, infrastructure, and finance) and countries with more than 100 syndicated loans (Qatar, Bahrain, Kuwait, Bulgaria, Croatia, Egypt, Vietnam, Panama, Pakistan, Nigeria, Saudi Arabia, Hungary, Romania, Colombia, Peru, Kazakhstan, Ukraine, Venezuela, South Africa, Poland, United Arab Emirates, Philippines, Malaysia, Argentina, Thailand, Mexico, Turkey, India, Indonesia, Russian Federation and Brazil). The dependent variables are number of loans (column 1), size of syndicated loans (\% of GDP) (column 2), banks per loan (column 3), and maturity of syndicated loans (in years) (column 4) in the country-sector-year. $\mathrm{MDB}_{\mathrm{cs}, \mathrm{t}}$ is a dummy equal to 1 if there is at least one MDB providing a syndicated loan in country-sector $c s$ at time $t$. The cumulative effect of $\mathrm{MDB}_{\mathrm{cs}, \mathrm{t}}$ between year $t-2$ and $t$, and the the p-value of a Wald test showing its significance, are also reported. The last rows show the averages of $\mathrm{MDB}_{\mathrm{cs}, \mathrm{t}}$ and the outcome variables in the estimation. Standard errors clustered at country-sector level in parentheses: ${ }^{*} \mathrm{p}<0.1,{ }^{* *} \mathrm{p}<0.05,{ }^{* * *} \mathrm{p}<0.01$. 
Table A7: Robustness: Monte Carlo Simulations

\begin{tabular}{lllll}
\hline & $\begin{array}{l}\text { Number } \\
\text { of loans } \\
(1)\end{array}$ & Size $(\%$ GDP) & Banks & Maturity \\
\cline { 2 - 5 }$\sum_{k=0}^{2} \beta_{k}$ & -0.001 & -0.001 & $(3)$ & $(4)$ \\
& $(0.024)$ & $(0.023)$ & $(0.690)$ & 0.001 \\
& & & & $(0.107)$ \\
\hline Sector-country FE & Yes & Yes & Yes & Yes \\
Sector-year FE & Yes & Yes & Yes & Yes \\
Country-year FE & Yes & Yes & Yes & Yes \\
No of Replications & 1,000 & 1,000 & 1,000 & 1,000 \\
\hline
\end{tabular}

Notes: The table reports the average cumulative effects from $t-2$ to $t$ from estimating equation 1 through Monte Carlo Simulations with 1,000 replications. The Monte Carlos Simulations are based on artificial datasets in which all variables are unchanged, except for treatment, which is randomly re-assigned to country-sectors-years. Standard errors across the 1,000 replications are reported in parentheses. 
Table A8: Robustness: Standard Errors Clustered at Country-Sector Level

\begin{tabular}{|c|c|c|c|c|}
\hline & $\begin{array}{l}\text { Number } \\
\text { of loans } \\
(1)\end{array}$ & $\begin{array}{l}\text { Size (\% GDP) } \\
\text { (2) }\end{array}$ & $\begin{array}{l}\text { Banks } \\
\text { (3) }\end{array}$ & $\begin{array}{l}\text { Maturity } \\
\text { (4) }\end{array}$ \\
\hline $\mathrm{MDB}_{\mathrm{cs}, \mathrm{t}}$ & $\begin{array}{l}0.8514^{*} \\
(0.482)\end{array}$ & $\begin{array}{l}0.0724^{* * *} \\
(0.023)\end{array}$ & $\begin{array}{l}0.5475^{* *} \\
(0.271)\end{array}$ & $\begin{array}{l}0.3581^{* * *} \\
(0.094)\end{array}$ \\
\hline $\mathrm{MDB}_{\mathrm{cs}, \mathrm{t}-1}$ & $\begin{array}{l}0.8166^{*} \\
(0.425)\end{array}$ & $\begin{array}{l}0.0293 \\
(0.025)\end{array}$ & $\begin{array}{l}0.7406^{* * *} \\
(0.223)\end{array}$ & $\begin{array}{l}0.1413 \\
(0.096)\end{array}$ \\
\hline $\mathrm{MDB}_{\mathrm{cs}, \mathrm{t}-2}$ & $\begin{array}{l}0.7803^{* *} \\
(0.394)\end{array}$ & $\begin{array}{l}0.0561^{* * *} \\
(0.020)\end{array}$ & $\begin{array}{l}0.6865^{* * *} \\
(0.236)\end{array}$ & $\begin{array}{l}0.2908^{* * *} \\
(0.095)\end{array}$ \\
\hline$\sum_{k=0}^{2} M D B_{\mathrm{cs}, \mathrm{t}-\mathrm{k}}$ & $2.448^{*}$ & $0.158^{* * *}$ & $1.975^{* * *}$ & $0.790^{* * *}$ \\
\hline Wald test: $p$ value & 0.0544 & 0.00313 & 0.000927 & 0.0000 \\
\hline Observations & 24,219 & 24,219 & 24,219 & 24,023 \\
\hline R-squared & 0.607 & 0.381 & 0.659 & 0.522 \\
\hline Sector-country FE & Yes & Yes & Yes & Yes \\
\hline Sector-year FE & Yes & Yes & Yes & Yes \\
\hline Country-year FE & Yes & Yes & Yes & Yes \\
\hline Average MDB & 0.0483 & 0.0483 & 0.0483 & 0.0477 \\
\hline Average Number of Loans & 0.760 & & & \\
\hline Average Size (\%GDP) & & 0.105 & & \\
\hline Average Banks & & & 1.526 & \\
\hline Average Maturity & & & & 0.755 \\
\hline
\end{tabular}

Notes: The table presents estimates of equation 1, but with standard errors clustered at the country-sector level. The dependent variables are number of loans (column 1), size of syndicated loans (\% of GDP) (column 2), banks per loan (column 3), and maturity of syndicated loans (in years) (column 4) in the country-sector-year. MDB $\mathrm{cs}_{\mathrm{t}, \mathrm{t}}$ is a dummy equal to 1 if there is at least one MDB providing a syndicated loan in country-sector $c s$ at time $t$. The cumulative effect of MDB $_{\mathrm{cs}, t}$ between year $t-2$ and $t$, and the the p-value of a Wald test showing its significance, are also reported. The last rows show the averages of $\mathrm{MDB}_{\mathrm{cs}, \mathrm{t}}$ and the outcome variables in the estimation. Standard errors clustered at country-sector level are in parentheses: ${ }^{*} \mathrm{p}<0.1,{ }^{* *} \mathrm{p}<0.05,{ }^{* * *} \mathrm{p}<0.01$. 
Table A9: Robustness: Mobilization effects in Smaller Sample

\begin{tabular}{|c|c|c|c|c|}
\hline & $\begin{array}{l}\text { Number } \\
\text { of loans } \\
(1)\end{array}$ & $\begin{array}{l}\text { Size (\% GDP) } \\
\text { (2) }\end{array}$ & $\begin{array}{l}\text { Banks } \\
\text { (3) }\end{array}$ & $\begin{array}{l}\text { Maturity } \\
\text { (4) }\end{array}$ \\
\hline $\mathrm{MDB}_{\mathrm{cs}, \mathrm{t}}$ & $\begin{array}{l}1.0061 \\
(0.640)\end{array}$ & $\begin{array}{l}0.0993^{* * *} \\
(0.026)\end{array}$ & $\begin{array}{l}0.6319^{* *} \\
(0.263)\end{array}$ & $\begin{array}{l}0.3898^{* * *} \\
(0.107)\end{array}$ \\
\hline $\mathrm{MDB}_{\mathrm{cs}, \mathrm{t}-1}$ & $\begin{array}{l}0.9431^{*} \\
(0.541)\end{array}$ & $\begin{array}{l}0.0408 \\
(0.030)\end{array}$ & $\begin{array}{l}0.8925^{* * *} \\
(0.253)\end{array}$ & $\begin{array}{l}0.1544 \\
(0.123)\end{array}$ \\
\hline $\mathrm{MDB}_{\mathrm{cs}, \mathrm{t}-2}$ & $\begin{array}{l}0.8880^{*} \\
(0.516)\end{array}$ & $\begin{array}{l}0.0411 \\
(0.025)\end{array}$ & $\begin{array}{l}0.7733^{* *} \\
(0.321)\end{array}$ & $\begin{array}{l}0.2252^{* *} \\
(0.100)\end{array}$ \\
\hline $\begin{array}{l}\sum_{k=0}^{2} M D B_{\mathrm{cst}-\mathrm{k}} \\
\text { Wald test : } p \text { value }\end{array}$ & $2.837^{*}$ & $0.181^{* * *}$ & $2.298^{* * *}$ & $0.769^{* * *}$ \\
\hline Observations & 13,869 & 13,869 & 13,869 & 13,708 \\
\hline R-squared & 0.606 & 0.431 & 0.652 & 0.518 \\
\hline Sector-country FE & Yes & Yes & Yes & Yes \\
\hline Sector-year FE & Yes & Yes & Yes & Yes \\
\hline Country-year FE & Yes & Yes & Yes & Yes \\
\hline Average MDB & 0.0713 & 0.0713 & 0.0713 & 0.0708 \\
\hline Average Number of Loans & 1.303 & & & \\
\hline Average Size (\%GDP) & & 0.160 & & \\
\hline Average Banks & & & 2.585 & \\
\hline Average Maturity & & & & 1.243 \\
\hline
\end{tabular}

Notes: The table presents estimates of equation 1 on syndicated loans in the sample used to estimate mobilization effects on corporate bonds. The dependent variables are number of loans (column 1), size of syndicated loans (\% of GDP) (column 2), banks per loan (column 3), and maturity of syndicated loans (in years) (column 4) in the country-sector-year. $\mathrm{MDB}_{\mathrm{cs}, \mathrm{t}}$ is a dummy equal to 1 if there is at least one MDB providing a syndicated loan in country-sector $c s$ at time $t$. The cumulative effect of $\mathrm{MDB}_{\mathrm{cs}, \mathrm{t}}$ between year $t-2$ and $t$, and the the p-value of a Wald test showing its significance, are also reported. The last rows show the averages of $\mathrm{MDB}_{\mathrm{cs}, \mathrm{t}}$ and the outcome variables in the estimation. Standard errors clustered at country-sector level in parentheses: ${ }^{*} \mathrm{p}<0.1,{ }^{* *} \mathrm{p}<0.05,{ }^{* * *} \mathrm{p}<0.01$. 